\title{
Neoproterozoic crustal growth at the margin of the East Gondwana continent - age and isotopic constraints from the easternmost inliers of Oman
}

\author{
Whitehouse, M.J. ${ }^{1}$, Pease, V.L. ${ }^{2}$ and Al Khirbash, S. ${ }^{3}$ \\ ${ }^{1}$ Swedish Museum of Natural History, SE-104 05 Stockholm, Sweden; \\ ${ }^{2}$ Dept. of Geological Sciences, Stockholm University, SE-106 91 Stockholm, Sweden \\ ${ }^{3}$ Dept. of Earth Sciences, Sultan Qaboos University, Al-Khodh, Muscat, Sultanate of Oman.
}

* corresponding author: martin.whitehouse@nrm.se

\begin{abstract}
The Jebel Ja'alan and Qalhat inliers of Oman represent the easternmost exposures in the Arabian peninsula of Neoproterozoic basement associated with the East African orogen and the assembly of East and West Gondwana. These inliers expose tonalitic gneisses and metasediments intruded by granodiorites and granites of the Ja'alan batholith. Zircon from the gneisses yield U-Pb SIMS ages of ca. 900-880 Ma, which are interpreted as crystallisation ages. These represent the oldest magmatic events associated with the closure of the Mozambique Ocean reported to date. Zircon of this age is also the dominant component in the metasediments. The Ja'alan batholith yields ages of ca. 840-825 Ma. Nd isotopes indicate that both the gneisses and the batholith range from juvenile to slightly more evolved, with $\varepsilon_{\mathrm{Nd}}(\mathrm{t})$ of +6 to +1.5 interpreted to reflect variable contamination by older, evolved continental material; this is also indicated by $>900 \mathrm{Ma}$ detrital zircon from the metasediments. The $\mathrm{Nd}$ data also contrast with the uniformly juvenile signature of younger, ca. $840 \mathrm{Ma}$, rocks of the Marbat region of southern Oman that lie structurally to the west. The Ja'alan and Qalhat inliers thus document eastward increasing age and continental influence, consistent with progressive development of arc rocks onto the western margin of East Gondwana, although the location and nature of the eastern continental block remains elusive.
\end{abstract}

Keywords: Neoproterozoic, Gondwana, Arabian basement, East African Orogen, geochronology, crustal growth 


\section{Introduction}

The Arabian-Nubian Shield (ANS), a tectonic collage of late-Neoproterozoic arc terranes, represents the northward extension of the East African Orogen (EAO) which formed during the amalgamation of East and West Gondwana (McWilliams, 1981; Stern, 1994). The western arc terranes were formed and assembled at ca. 800-700 Ma while the eastern arc terranes are somewhat younger at ca. 740-620 Ma (Stoeser \& Frost, 2006). Despite this apparent younging to the east, which is broadly consistent with progressive arc accretion along the margin of West Gondwana, the oldest (Paleoproterozoic to Neoarchean) continental (or continentalinfluenced) components identified in the Arabian Shield are located along its eastern margin in the Khida region of Saudi Arabia and in the terranes of Yemen (Whitehouse et al., 2001a,b; Yeshanew et al., 2015) raising questions about the nature of the basement to the east and its role in the orogen. However, the basement of the eastern Arabian peninsula, which has the potential to elucidate the eastern terrane accretionary history, is largely inaccessible and mostly concealed beneath thick Phanerozoic sedimentary cover, with a gap of $>800 \mathrm{~km}$ to the east of the Arabian Shield before the next exposed basement occurs in southern Oman (Fig. 1). Limited geochronology for this concealed basement has come from rare xenoliths of ca. 560-545 Ma igneous rocks and > ca. 590 Ma metasediments in salt domes of western Oman and the United Arab Emirates (Thomas et al., 2015), but isotopic data addressing its nature is lacking. Significant exposures of eastern Arabian basement occur east of Salalah in the Marbat region of southern Oman where they have been extensively investigated (Mercolli, 2006; Rantakokko et al., 2014), on the island of Socotra, Yemen (Whitehouse et al., 2012, Denèle et al., 2012) which was located immediately to the east of the Marbat region prior to the opening of the Gulf of Aden, and in the Jebel Ja'alan, Qalhat and Al Jobah regions of Oman. Intriguingly, the 840 - 790 Ma juvenile arc rocks of the Marbat region have closer isotopic affinities to the older, isotopically juvenile western arc terranes of the Arabian Shield than with the younger, less juvenile eastern arc terranes or the continental terranes exposed at the eastern shield margin and have been proposed to reflect arc accretion at the opposing margin of the Mozambique Ocean, i.e. along East Gondwana (Rantakokko et al., 2014). We present zircon U-Pb (SIMS) geochronological and whole-rock $\mathrm{Nd}$ isotopic results from the basement inliers of Jebel Ja'alan and Qalhat in Oman which, assuming a continued, roughly north-south trend to the EAO, lie structurally east of Marbat (and Socotra) basement, to further investigate the nature and possible affinities of the eastern Arabian basement. We 
conclude that these inliers likely represent the earliest stage of arc accretion on the eastern side of the Mozambique Ocean, proximal to the East Gondwana continent.

\section{Geological background, unit descriptions, and sampling}

Precambrian basement rocks occur as inliers in eastern Oman at two locations (Fig. 1). In the Jebel Ja'alan area, east of the town of Al Kamil, a basement window of ca. $50 \mathrm{~km}^{2}$ is exposed. It is unconformably overlain in its southern and central parts by late-Cretaceous (Maastrichtian) sediments and fault-bounded to the north by Tertiary sediments, both of which post-date thrust emplacement of the Hawasina metamorphic and Semail ophiolite nappes and the east Oman ophiolite nappe which occur respectively to the north and southeast of Jebel Ja'alan (Fig. 1 of Rollinson et al., 2014). Similar rock associations are also exposed in a narrow, roughly north-south trending belt of wadi-dissected outcrops on the flank of Jebel Hullayat, to the south of the coastal village of Qalhat approximately $20 \mathrm{~km}$ due north of Jebel Ja'alan. These outliers are $750 \mathrm{~km}$ northeast of the well-documented Precambrian rocks of the Marbat (Salalah) region in southern Oman and over $1400 \mathrm{~km}$ from the nearest Precambrian exposures in either the Saudi Arabian shield or mainland Yemen.

In the Jebel Ja'alan area, tonalite and granodiorite of plutonic suite known as the Ja'alan batholith intrude a metamorphic basement comprised of the Ja'alan Gneiss and Al Wafi Mica Schist (Roger et al., 1991). In the Qalhat area, granodioritic to granitic plutonic rocks and the host metamorphic basement are presumed to be equivalent to the Ja'alan batholith and the Ja'alan gneiss, respectively (Wyns et al., 1992). We therefore extend the Ja'alan nomenclature of Roger et al. (1991) to Qalhat. The major crystalline units exposed in the study area are described below and shown in figure 2 .

$J a$ 'alan Gneiss $(J G \& J G A)$. The Ja'alan gneiss is best exposed in the Jebel Ja'alan region (Roger et al., 1991) and is comprised of two main phases: i) banded biotite-garnet gneiss and migmatite $(J G)$, and ii) banded amphibole gneiss (JGA). The biotite-garnet gneiss and migmatite are intimately associated on an outcrop scale (Fig. 2a-c). They are variably leucocratic, light to dark blue-grey or pink, and fine to medium grained. They are strongly foliated and folded. Calc-silicate gneiss locally forms decimeter-long boudins within the more ductile biotite-garnet gneiss gneiss and migmatite unit $(J G)$. The $J G$ unit exhibits an early, discontinuous metamorphic banding defined by the alternation of thick leucocratic 
bands and thin biotite-rich bands. The banding is often folded into tight to isoclinal folds with axial-planar biotite defining the foliation. Both mesocratic biotite-rich (likely metasedimentary) bands, which at Qalhat includes metapelite, and the leucocratic banded orthogneiss share a common mineralogy of quartz, plagioclase, potassium feldspar, biotite, and relict garnet. The migmatitic rocks are cut by veins of garnet-biotite granodiorite.

The amphibole gneiss is dark green to grey, laterally extensive, and generally, strongly foliated and banded, but also occurs as more homogeneous resistent boudins (Fig. 2d). Amphibolite and pyroxene-amphibole gneiss are present, as well as fine-grained, wellbanded, and granular-porphyroclastic varieties. Pegmatitic patches with amphibole and plagioclase are abundant. The finer-grained varieties are probably derived from dolerite or basalt, whereas the coarser grained rocks may be related to metadiorite.

Al Wafi Mica Schist (WM). The banded biotite-sillimanite mica schist and gneiss is best exposed in northwestern Jebel Ja'alan where it is in thrust contact with the Ja'alan gneiss. It is finer-grained and darker colored than the Ja'alan gneiss, and occurs as banded, foliated schist (Fig. 2e) and spotted (hornfelsic) mica schist. Both types are intruded by granitic veins (Fig. 2e). The Al Wafi mica schist also locally contains boudins of calc-silicate gneiss. Metapelitic schist in the Qalhat region is inferred to be equivalent (Fig. 2f).

Tonalite and Granodiorite (TG). The gneisses are intruded by numerous small stocks and thick veins that range in composition from biotite-garnet tonalite to granodiorite (Fig. $2 \mathrm{~g}, \mathrm{~h}$ ). The rocks are light colored, medium-grained, commonly contain garnet, and vary in composition from quartz-diorite to tonalite-granodiorite. They are foliated to different degrees and may have been generated during anatexis of the host gneiss.

Ja'alan Batholith (JDQ, JGT, JGG). The Ja'alan batholith intrudes the gneisses (JG, JGA, $W M$ ) and anatectic granitoids (TG) (Fig. 2i, j). Three successively intruded units include diorite to quartz diorite $(J D Q)$, granodiorite to tonalite (JGT), and granite to granodiorite $(J G G)$. The hornblende-biotite diorite to quartz diorite $(J D Q)$ forms an elongate northeasttrending body on the eastern side of the batholith. It is cut by the hornblende-biotite granite to granodiorite $(J G G)$ which contains inclusions of more mafic diorite and quartz diorite $(J D Q)$. It is also cut by small bodies of granodiorite to tonalite (JGT). The fine- to medium-grained diorite to quartz diorite is either uniform in crystal size $(1.5 \mathrm{~mm})$ or porphyritic with 
plagioclase phenocrysts up to $2 \mathrm{~cm}$ long. A pronounced magmatic foliation is defined by amphibole, biotite, and plagioclase.

The granodiorite to tonalite (JGT) compositional phase is generally pink to grey and medium grained. Planar flow structures are rare and sparse inclusions of diorite to quartz diorite (JDQ) are present. It is composed of inequigranular plagioclase, biotite, quartz, and green hornblende. Potassium feldspar (5-30\%) is commonly present in the granodiorite but generally absent from the tonalite. Accessory minerals present include oxides, titanite, apatite, and zircon.

The biotite \pm hornblende granite to granodiorite unit $(J G G)$ comprises around two-thirds of the Ja'alan batholith. Along its northwestern contact the migmatitic foliation of the Ja'alan gneiss closely mimics the contact suggesting a syntectonic relationship, synchronous with partial migmatization of the host gneiss. The granite and granodiorite are pale red, fine-to mediumgrained, commonly equigranular but sometimes slightly porphyritic with potassium feldspar phenocrysts. Inclusions of dioritic composition gneisses are present. This unit is compositionally variable from granodiorite to granite. Its mineralogy includes quartz, plagioclase, potassium feldspar, biotite, and green hornblende (2-15\%). Accessory minerals include oxides, titanite, apatite, and zircon.

A white, fine-grained aplitic granite (GR) intudes the Al Wafi mica schist (Fig. 2e). Potassium feldspar poikilitically encloses plagioclase. Quartz forms polycrystalline patches and garnet occurs as small $(<0.5 \mathrm{~mm})$ subhedral crystals. Accessory minerals include muscovite, zircon, and apatite.

Polyphase ductile deformation of the crystalline basement in the region developed during regional high-grade metamorphism that reached upper amphibolite facies during intrusion of the Ja'alan batholith (Roger et al., 1991; Wyns et al., 1992). Two successive phases of deformation are documented: 1) An older phase defined by a metamorphic foliation parallel to layering (S1) in banded gneiss and amphibolite, and also present as relics within the migmatites; 2) a younger phase defined by tight to isoclinal similar folds (F2) of decimeter to 10 m-scale with a variably developed axial planar foliation (S2) (Roger et al., 1991). S1 is commonly transposed into S2, especially in the migmatitic gneisses. The second phase of deformation corresponded to peak regional metamorphism of the basement rocks and is 
recorded by a mineral assemblage of biotite + sillimanite + garnet + cordierite + potassium feldspar, as well as partial migmatization of the banded gneiss. S2 is inferred to be contemporaneous with intrusion of the Ja'alan batholith.

Both the metamorphic basement and the plutonic rocks are cut by late doleritic, microgranitic, and porphyritic dykes $(D I)$. These comprise a minor component of the Ja'alan region. They have chill margins, are subparallel, steeply dipping and strike SE-NW. They post-date basement metamorphism and deformation, and the intrusion of the Ja'alan batholith.

Existing geochronology from the region is limited. Single-zircon lead evaporation ages of zircons from two samples of the Ja'alan batholith, the biotite-garnet tonalite $(T G)$ and the hornblende-biotite granodiorite $(J G T)$, yielded ages within error of each other: $826 \pm 9 \mathrm{Ma}$ and $824 \pm 8 \mathrm{Ma}$ (Roger et al., 1991). These ages were interpreted to represent the crystallization and emplacement age of the batholith, and indicate no age difference between the two compositional phases. A sample of $J G G$ yielded ages of $872 \pm 17 \mathrm{Ma}$ (K-Ar on biotite) and $848 \pm 15$ (Rb-Sr on biotite and whole rock; Glennie et al., 1974). Previous work also includes a $\mathrm{Rb}-\mathrm{Sr}$ whole rock age from seven samples collected in the southern part of the

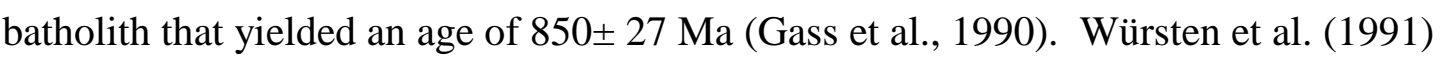
reported K-Ar biotite and muscovite cooling ages around $815 \mathrm{Ma}$.

For the present study, fifteen samples were collected across the two inliers, including three from the Qalhat area and twelve from Jebel Ja'alan (Fig. 1). Samples typical of the units and/or providing critical cross-cutting relationships for constraining the relative timing of events were collected (Fig. 2). These comprise nine samples from the pre-batholith basement (three gneisses, two amphibole gneisses, one schist, two tonalites and one granitic sheet), five samples of the Ja'alan batholith suite (granodiorite, diorite, and tonalite), as well as a single late granite porphyry.

\section{Analytical methods}

Major element concentrations were determined on fused glass beads by X-ray fluorescence (XRF) using a Rigaku XRF at the PetroTectonics Analytical Facility, Stockholm University. The concentrations of 10 major elements were determined by comparison of X-ray intensities for each element with calibration lines constructed from the analysis of known concentrations 
in 24 international standards of known concentrations. USGS standards AGV 2 and RGM 1 were analyzed as unknowns during the analytical session for data quality control. Data are presented in Table S1.

Zircon was separated from samples using conventional disaggregation followed by Wilfley table and heavy liquid processing. An aliquot of the crushed sample was milled to powder for geochemical and Sm-Nd analysis. Separated zircon grains were hand-picked, mounted in epoxy, and polished prior to cathodoluminescence (CL) imaging using an Hitachi s4300 SEM and ETP-SEMRA CL detector at the Swedish Museum of Natural History. U-Pb geochronology was performed using a CAMECA IMS1280 large-geometry ion microprobe at the Nordsim facility, NRM. Geochronological analyses follow routine protocols outlined by Whitehouse et al. (1999) and Whitehouse and Kamber (2005). A ca. 6 nA, - 13 kV O${ }_{2}^{-}$primary beam (imaged aperture of $150 \mu \mathrm{m}$ corresponding to a spot diameter on the sample of ca. 15 $\mu \mathrm{m})$ was used to sputter $+10 \mathrm{kV}$ secondary ions which were admitted to the mass spectrometer and detected in a peak-hopping sequence using a single ion-counting electron multiplier. The mass spectrometer was operated at a mass resolution $(M / \Delta M)$ of 5400 , sufficient to separate all species of interest from molecular interferences. Each analysis comprised a 70 second pre-sputter to remove the Au-coating and allow the secondary beam to stabilize, centering of the secondary beam in the field aperture, energy optimization in the 45 $\mathrm{eV}$ energy window, mass calibration adjustment using the ${ }^{90} \mathrm{Zr}_{2}{ }^{16} \mathrm{O}$ peak, and 12 cycles through the species of interest. Groups of analyses were performed in fully automated sequences, regularly interspersing standard analyses with those of the sample zircon grains. Data reduction utilized an in-house developed suite of software. $\mathrm{Pb}$-isotope ratios were corrected for common $\mathrm{Pb}$ estimated from measured ${ }^{204} \mathrm{~Pb}$ assuming the present-day terrestrial $\mathrm{Pb}$ isotope composition estimated from the model of Stacey and Kramers (1975); where the ${ }^{204} \mathrm{~Pb}$ count was statistically insignificant relative to the long-term background on the EM, no correction was applied. $\mathrm{U} / \mathrm{Pb}$ ratios were calibrated using an empirical power-law relationship between ${ }^{206} \mathrm{~Pb} /{ }^{238} \mathrm{U}$ and ${ }^{238} \mathrm{U}^{16} \mathrm{O}_{2} /{ }^{238} \mathrm{U}$ from regular measurements of the $1065 \mathrm{Ma}$ Geostandards 91500 zircon (Wiedenbeck et al., 1995). Age calculations assume the decay constant recommendations of Steiger and Jäger (1977) and utilize the routines of Isoplot-Ex (Ludwig, 2004). All age uncertainties include uncertainties on the decay constants and are reported at $2 \sigma$; for Concordia ages, the MSWD on combined equivalence and concordance is reported following the recommendation of Ludwig (1998). Zircon U-Pb data are presented in Table S2. 
Powdered whole rock was combined with a mixed ${ }^{149} \mathrm{Sm}^{-150} \mathrm{Nd}$ spike, dissolved in HF/HNO3, and $\mathrm{Sm}$ and $\mathrm{Nd}$ separated using standard ion exchange chromatography. The total process $\mathrm{Nd}$ blank was $0.10 \mathrm{ng}$. Isotope ratios were measured on a Thermo Scientific TRITON TIMS in static multi-collector mode on rhenium double filaments, with $\mathrm{Nd}$ isotope ratios normalized to ${ }^{146} \mathrm{Nd} /{ }^{144} \mathrm{Nd}=0.7219$. External precision on ${ }^{143} \mathrm{Nd} /{ }^{144} \mathrm{Nd}$ based on long-term replicates of the La Jolla Nd standard is $11 \mathrm{ppm}$ and the mean ${ }^{143} \mathrm{Nd} /{ }^{144} \mathrm{Nd}$ ratio is within error of the accepted value of 0.511847 , thus requiring no accuracy correction. Sm-Nd data and derived parameters are calculated using the ${ }^{147} \mathrm{Sm}$ decay constant of Lugmair and Marti (1978), the chondritic uniform reservoir (CHUR) values of Jacobsen and Wasserburg (1980) and the depleted mantle model of DePaolo et al. (1991) are presented in Table 2.

\section{Results}

\section{Major element geochemistry}

Major element data were used to complement and confirm field naming of units, as shown in Table 1. The samples define a sub-alkaline trend typical of arc rocks on a plot of alkalis $\left(\mathrm{Na}_{2} \mathrm{O}+\mathrm{K}_{2} \mathrm{O}\right)$ vs. $\mathrm{SiO}_{2}$ and, with the exception of the true granite samples, represent tonalitetrondhjemite-granodiorites (Fig. 3).

\section{$\mathrm{U}-\mathrm{Pb}$ zircon geochronology}

OM05-40, granite sheet cutting Al-Wafi schist (unit WM). Zircon separated from this sample are pale-pink, clear to turbid, euhedral prisms with length/width ratios up to 4. CL imaging (Fig. 4a) reveals a range of internal textures from rounded, oscillatory zoned cores overgrown by medium to dark CL-luminescent zoned rims to structureless cores or single-phase, oscillatory zoned grains. Eleven analyses were performed on nine grains, with two core/rim pairs. U contents range from 104 to $907 \mathrm{ppm}$ (average $357 \mathrm{ppm}$ ) and $\mathrm{Th} / \mathrm{U}$ ratios from 0.09 to 1.3 (average 0.7). Many grains have high common $\mathrm{Pb}$ contents and on a concordia plot (Fig. 4a) define a sub-horizontal (i.e. recent) Pb-loss trend. Both of the analysed rims yield ages younger than their respective cores and different from each other; this most likely also reflects variable $\mathrm{Pb}$-loss and these ages are therefore accorded no significance. The three oldest concordant analyses combine to yield a concordia age of $881.4 \pm 8.3($ MSWD $=0.45)$ which is tentatively assigned as the age of the granite sheet, although the paucity of high-quality zircon from this sample limits confidence in this age. 
OM05-41, Al-Wafi mica schist (unit WM). The Al Wafi mica shist yielded generally small, colourless to pale-pink zircon with a range of morphologies from rounded to euhedral prismatic. As expected from a detrital population, CL imaging (Fig. 4b) reveals a wide range of internal structures and variable brightness and zoning in CL, with some clear older cores that are rounded and overgrown by oscillatory zoned rims. Twenty-six analyses were performed on twenty-four grains, with two core/rim pairs. Eleven analyses are $>5 \%$ discordant, possibly the result of both ancient and recent $\mathrm{Pb}$-loss, and are omitted from further consideration. The remaining concordant grains yield two distinct groups of ages, the oldest from $\sim 1870$ to $\sim 1620 \mathrm{Ma}$ and the youngest from $\sim 920$ to $\sim 850 \mathrm{Ma}$ (Fig. 4b). Of the two core/rim pairs, one yields a concordant ca. $870 \mathrm{Ma}$ rim age with an older but discordant core (minimum age ca, $1550 \mathrm{Ma}$ ), while the other yields a concordant ca $860 \mathrm{Ma}$ core with a highly discordant, younger rim .There is a peak in the distribution at $870 \mathrm{Ma}$ defined by three analyses and a lower-age shoulder comprising two analyses. The majority of the grains in the Al Wafi schist are considered to represent detrital input into its sedimentary protolith. However, use of the youngest grains to constrain the depositional age is complicated by the possibility of $\mathrm{Pb}$-loss during younger events. Of the two ca. $850 \mathrm{Ma}$ analyses, one represents a small CL-dark core of a grain whose rim clearly documents extensive $\mathrm{Pb}$-loss, while the other is a CL-dark grain with the highest $U$ concentration $(650 \mathrm{ppm})$ of the concordant group and notably as high as other grains in the sample that clearly have experienced $\mathrm{Pb}$-loss. A more realistic estimate may be placed on the minimum depositional age of $871 \pm 18 \mathrm{Ma}$ by the rim analysis of grain 15 , which has a low $\mathrm{Th} / \mathrm{U}$ ratio (0.12) and likely represents metamorphic recrystallization during an event that affected the schist.

OM05-42, garnet (+muscovite?) granite (unit TG). This sample yielded euhedral prismatic, colourless, turbid zircon grains with length-width ratios from 2 to 4 . In CL (not shown), all grains are uniformly dark and only faint internal zoning is discernible. Ten grains were analysed, all with exceedingly high $\mathrm{U}$ contents from 5970 to $22600 \mathrm{ppm}$ and $\mathrm{Th} / \mathrm{U}$ ratios from 0.26 to 1.5 . The $\mathrm{U}-\mathrm{Pb}$ data are all highly discordant (62 to $92 \%$ ) and several grains are affected by large common $\mathrm{Pb}$ contents $\left(f_{206}>5 \%\right)$. Consequently, no meaningful age can be obtained from this sample beyond an absolute minimum age of $704 \pm 30 \mathrm{Ma}$ for the analysis with the lowest ${ }^{207} \mathrm{~Pb} /{ }^{206} \mathrm{~Pb}$ ratio (assuming present day $\mathrm{Pb}$-loss).

OM05-45 foliated granodiorite (unit JTG, cuts Al Wafi schists). Zircon from this sample are typically clear, colourless to pale-pink euhedral prisms with length/width ratios up to 6 . They 
sometimes contain mineral (e.g. apatite) or melt inclusions. Simple internal structures are revealed by CL imaging (Fig. 4c), with dominant oscillatory zoning and few apparent older cores. Sixteen analyses were made on thirteen grains, with three inner/core - outer/rim pairs. The analyses exhibit a wide range in $\mathrm{U}$ concentration and $\mathrm{Th} / \mathrm{U}$ ratio, from 50 to $1730 \mathrm{ppm}$ (average 410) and from 0.11 to 1.23 (average 0.47), respectively. Omitting the seven youngest analyses that define a clear $\mathrm{Pb}$-loss trend in ${ }^{206} \mathrm{~Pb} /{ }^{238} \mathrm{U}$ ages, the remaining nine analyses (Fig. 4 c) define a somewhat poorly constrained concordia age of $843.1 \pm 6.6(\mathrm{MSWD}=1.8)$. Omission of the oldest analysis improves the probability of fit and results in an age of $839.8 \pm$ $3.4(\mathrm{MSWD}=0.86)$ which is considered to date the crystallization of the granordiorite.

OM05-46, biotite-granite (unit JGG). The sample yielded euhedral prismatic zircon grains with length/width ratios up to 4 . They are colourless to light-brown and either transparent or turbid, often extensively fractured, with several grains containing mineral (e.g. apatite) and/or melt inclusions. In CL (Fig. 5a), most grains are medium to dark and characterized by finescale oscillatory zoning with no evident older cores. Nine spot analyses were performed, one of which was discarded due to very high common $\mathrm{Pb}\left(f_{206}>5 \%\right)$. The grains have moderate $\mathrm{U}$ contents, ranging from 286 to $1340 \mathrm{ppm}$ and $\mathrm{Th} / \mathrm{U}$ from 0.48 to 2.0. The analyses define a sub-horizontal recent $\mathrm{Pb}$-loss trend in the concordia diagram (Fig. 5a). The oldest analysis is slightly reverse discordant and its ${ }^{206} \mathrm{~Pb} /{ }^{238} \mathrm{U}$ age of $856 \pm 18 \mathrm{Ma}$ is likely affected by its high $\mathrm{U}$ and Th content. The Pb-loss trend precludes calculation of a concordia age, but the eight analysed grains with relatively low common $\mathrm{Pb}$ contents yield a weighted average ${ }^{207} \mathrm{~Pb} /{ }^{206} \mathrm{~Pb}$ age of $826 \pm 13 \mathrm{Ma}(\mathrm{MSWD}=0.85)$, which is interpreted as dating the crystallization age of the biotite-granite.

OM05-47 granodiorite (unit JGT). The sample yielded euhedral, prismatic zircon grains that are colourless and clear, with length/width ratios of 2 to 4 . Small mineral or melt inclusions occur in a few grains. CL images (Fig. 5b) reveal oscillatory zoned interiors with complex high-contrast, convolute patterns but few, if any, distinct cores. Twenty analyses were made on seventeen grains, with three inner/core - outer/rim pairs. U contents range from 66 to 774 ppm (average $275 \mathrm{ppm}$ ) and $\mathrm{Th} / \mathrm{U}$ ratios from 0.14 to 2.3 (average 0.93 ). Common $\mathrm{Pb}$ corrected ${ }^{206} \mathrm{~Pb} /{ }^{238} \mathrm{U}$ ages range from ca. $860 \mathrm{Ma}$ to $800 \mathrm{Ma}$. The oldest age was obtained on a CL-dark rim from the only apparent true core/rim pair; its core, having clearly lost $\mathrm{Pb}$, yields the youngest age. The $\mathrm{U}, \mathrm{Th}$ and $\mathrm{Pb}$ signals changed during the course of the rim analysis, suggesting that the ion beam depth-profiled into the older core; this analysis is therefore 
regarded as an outlier and omitted from further consideration. The thirteen oldest of the remaining analyses yield a concordia age (Fig. 5b) of 839.4 \pm 4.7 (MSWD $=1.4)$ which interpreted to date the crystallization age of the granodiorite, with the youngest analyses attributed to $\mathrm{Pb}$-loss.

OM05-48 granite porphyry (unit DI). Zircon grains from this sample are euhedral (though many grains are fragmentary) and have length-width ratios up to 4 . They are colourless and clear to slightly turbid. CL images (Fig. 5c) reveal these grains to be single-phase, dark and weakly oscillatory and/or sector zoned. Melt or mineral inclusions occur in about $20 \%$ of the picked grains. The eighteen grains analysed have a restricted range in $U$ concentration and $\mathrm{Th} / \mathrm{U}$ ratio, respectively 244 to $564 \mathrm{ppm}$ (average $383 \mathrm{ppm}$ ) and 0.59 to 0.99 (average 0.81 ). Omitting the four youngest grains, which appear to have experienced minor $\mathrm{Pb}$-loss, and a single grain with excessive common $\mathrm{Pb}$, the remaining thirteen analyses yield a concordia age (Fig. 5c) of $760.0 \pm 3.3(\mathrm{MSWD}=1.1$ ) which likely dates the intrusion of the granite porphyry.

OM06-01 garnet-biotite tonalite (unit TG). Zircon grains from this sample are generally small, light pink in colour, well-faceted and stubby to acicular (length/width ratios from 2 to 5). In CL (Fig. 6a) most grains exhibit rather homogeneous, medium-bright zoning in their central regions, which passes into brighter and then darker outer parts. Occasional embayments are developed and fine oscillatory zoning is absent. In rare grains with apparently early/older cores, these are small, rounded and CL-dark. Eighteen grains were analysed, with $U$ concentrations ranging from 51 to $750 \mathrm{ppm}$ (average $184 \mathrm{ppm}$ ) and $\mathrm{Th} / \mathrm{U}$ ratios from 0.05 to 0.66 (average 0.35 ); Th contents are relatively constant and the lowest $\mathrm{Th} / \mathrm{U}$ values reflect U-enrichment in CL-dark outer parts of some grains. Omitting the five analyses with the youngest 207-corrected ages, which define a sub-horizontal recent $\mathrm{Pb}$-loss trend on the inverse concordia diagram (Fig. 6a), thirteen analyses yield a concordia age of $822.8 \pm 3.4 \mathrm{Ma}(\mathrm{MSWD}=0.85)$ which is interpreted to date the crystallization of the tonalite.

OM06-02 migmatitic gneiss (unit JG). Zircon grains from the migmatitic gneiss are light pink to brown in colour, euhedral, stubby to elongate prisms with length/width ratios between 2 and 4. CL images (Fig. 6b) reveal grain centres similar in appearance to those of the adjacent grey gneiss (OM06-03), i.e. moderately luminescent, largely unzoned regions passing into a weakly oscillatory zoned phase, with occasional rounded CL-dark cores. In contrast to the 
gneiss, however, many grains in the migmatite are mantled by broad, oscillatory zoned, CLdark rims. Of the thirty-two analyses performed on twenty-one grains, fourteen represent cores and seventeen rims (a single attempted rim analysis represents a core-rim mixture and is discounted from further consideration). As with CL, the cores exhibit similar characteristics in their geochemistry to the grains from OM06-03, with U concentrations ranging from 95 to $830 \mathrm{ppm}$ (average $270 \mathrm{ppm}$ ) and $\mathrm{Th} / \mathrm{U}$ ratios from 0.09 to 1.4 (average 0.69); a single outlier corresponds to one of the highest $\mathrm{U}$ analyses. Most of the core analyses exhibit a pronounced $\mathrm{Pb}$-loss trend in their 207-corrected ages, with the most discordant analyses lying above concordia on a sub-horizontal, recent Pb-loss trajectory (Fig, 6b). The oldest four concordant cores yield a concordia age of $905.4 \pm 6.8 \mathrm{Ma}(\mathrm{MSWD}=1.1)$, within error of the inferred magmatic age from sample OM06-03 and therefore the likely protolith to the migmatitic gneiss. Rim analyses are characterized by considerably higher $U$ concentrations, ranging from 450 to $2840 \mathrm{ppm}$ (average $1210 \mathrm{ppm}$ ) and much lower Th/U ratios from 0.01 to 0.30 (average 0.06). Most of these rims have clearly experienced recent $\mathrm{Pb}$-loss, plotting along a subhorizontal trend in the concordia diagram. Omitting these analyses, as well as the reversely discordant oldest rim analysis, which appears to be affected by a U/Pb calibration issue and/or radiogenic $\mathrm{Pb}$-gain, five analyses define a concordia age of 831.1 $\pm 5.9 \mathrm{Ma}(\mathrm{MSWD}=1.2$ ) and are interpreted to date the formation of the CL-dark rims during migmatisation.

OM06-03 grey gneiss (unit JG). Zircon grains extracted from this sample are generally light pink in colour and elongate to acicular with length/width ratios between 2 and 5. In CL (Fig. 6c), the grains are typically magmatic in appearance, exhibiting relatively simple, homogeneous, mostly unzoned central CL-medium regions that grade out to weakly oscillatory zoned CL-medium/dark rims. A few grains have CL-dark, rounded, unzoned central regions. Twenty-six analyses were performed on nineteen grains, with the analysed regions yielding $U$ concentrations in the range $32-640 \mathrm{ppm}$ (average $180 \mathrm{ppm}$ ) and $\mathrm{Th} / \mathrm{U}$ ratios from 0.14 to 1.1 (average 0.62 ). The two low, clearly outlying, Th/U ratios corresponding to CL-dark rims with the highest U contents. On a plot of 207-corrected ${ }^{206} \mathrm{~Pb} /{ }^{238} \mathrm{U}$ ages, the seven youngest analyses (including two high- $\mathrm{U}$, low $\mathrm{Th} / \mathrm{U}$ rims) define a $\mathrm{Pb}$-loss trend, with the remainder defining an age plateau. Within the latter group, there are no systematic differences between apparent cores and rims and, when plotted on inverse Concordia (Fig. 6c), these nineteen concordant analyses yield an age of 902.2 $\pm 3.4 \mathrm{Ma}$ (MSWD = 1.2), which is interpreted as the magmatic crystallization age of the gneiss protolith. The rounded, CL-dark cores likely represent an early magmatic phase, of 
unresolvable age, that underwent minor resorption before growth of the zoned rims. $\mathrm{The} \mathrm{Pb}-$ loss pattern in comprises both recent (sub-horizontal) $\mathrm{Pb}$-loss and older (parallel to concordia) Pb-loss at ca. $800 \mathrm{Ma}$ (Fig. 6c).

OM06-04 fine-grained amphibolite (unit JGA). Zircon grains separated from this sample are typically elongate and light pink in colour, with length/width ratios from 2 to 5. CL images (Fig. 7a) reveal a simple suite of homogeneous to weakly-zoned, single-phase CL-dark grains, with no older cores present and an exceedingly thin CL-bright rim. Melt inclusions are common. Eighteen grains were analysed, U concentrations range from 124 to ca. $1508 \mathrm{ppm}$ (average $441 \mathrm{ppm}$ ) and $\mathrm{Th} / \mathrm{U}$ ratios from 0.7 to 1.7 (average 0.95 ). Omitting the three youngest analyses, which likely record $\mathrm{Pb}$-loss, the remaining fifteen analyses yield a concordia age (Fig. 7a) of $887.5 \pm 3.6 \mathrm{Ma}(\mathrm{MSWD}=1.1)$ that is interpreted to date the crystallization of the amphibolite protolith.

OM06-05 coarse-grained amphibolite (unit JGA). This coarse-grained amphibolite yielded a markedly more diverse zircon population than its fine-grained counterpart. Light-pink grains are euhedral and elongate, with length/width ratios from 2 to 5. In CL (Fig. 7b), a few singlephase, dark grains similar to those in sample OM06-05 are present, but most grains are polyphase with CL-dark cores surrounded by thick oscillatory zoned, moderately CL-bright rims. In some cases the rims appears to vein the cores, resulting in a disjointed appearance. A total of twenty-eight analyses were performed on seventeen grains, including eight core/rim pairs. Core analyses range in $\mathrm{U}$ content from 182 to $3220 \mathrm{ppm}$ (average $1060 \mathrm{ppm}$ ) and Th/U from 0.2 to 3.3 (average 1.3). Two high $U$ ( \& Th) cores plot reversely discordant due to a likely matrix effect on the $\mathrm{U} / \mathrm{Pb}$ calibration, while three analyses yield younger ages than the main group of cores that suggests Pb-loss. The remaining eight cores combine to yield a concordia age of $891.0 \pm 5.3 \mathrm{Ma}(\mathrm{MSWD}=1.4)$ that is interpreted to date the crystallization of the zircon cores. Rim analyses in this sample have U concentrations ranging from 206 to $896 \mathrm{ppm}$ (average $383 \mathrm{ppm}$ ) and $\mathrm{Th} / \mathrm{U}$ ratios from 0.05 to 0.24 (average 0.13 ), with a single outlier. Two rims yield ${ }^{206} \mathrm{~Pb} /{ }^{238} \mathrm{U}$ ages of ca. $855 \mathrm{Ma}$, which are older than the main rim group despite no obvious morphological differences. One of these rims exhibited an unstable secondary ion emission and its older age may therefore be an analytical artifact and additionally three rims yield younger ages that likely result from $\mathrm{Pb}$ loss. Omitting these analyses, the main group of nine analyses yield a concordia age (Fig. 7b) of $825.3 \pm 3.9 \mathrm{Ma}$ (MSWD $=0.84)$ that is interpreted to date the event responsible for the rim overgrowths. 
OM06-06 garnet-biotite metapelite (unit JG). This sample yielded a morphologically diverse population of zircon, consistent with its likely sedimentary origin. Separated grains range from equant, with rounded or multi-facetted outer surfaces, to elongated, occasionally acicular morphology. The grains are transparent to light pink or yellow in colour, with length/width ratios ranging up to 5. Internal structures revealed by CL (Fig. 8) include homogeneous, unzoned grains as well as grains that exhibit clear core-rim structures with truncated zoning. Seventy-seven analyses were performed on seventy-one grains and, while thirty-three of these analyses represent cores in polyphase grains, few rims were sufficient in size to permit targeting. These analyses yield a broad range of ages ranging up to Neoarchean (Fig. 8) with the oldest, albeit $6 \%$ discordant, providing a minimum ${ }^{207} \mathrm{~Pb} /{ }^{206} \mathrm{~Pb}$ age of $2650 \pm 6 \mathrm{Ma}$. Twenty-four analyses (thirteen concordant at $>95 \%$ ) yield ages in excess of $1 \mathrm{Ga}$. Most of the population has ${ }^{206} \mathrm{~Pb} /{ }^{238} \mathrm{U}$ ages in the range $\sim 940-800 \mathrm{Ma}$. Morphology, internal texture and zircon U-Th chemistry are of limited help in deciphering the younger, <940 Ma population, although four analyses with exceedingly low $\mathrm{Th} / \mathrm{U}(<0.05)$, typical of metamorphic zircon, are all younger than $\sim 840 \mathrm{Ma}$. On a probability density plot (not shown), there is a dominant peak at 893 Ma comprising grains of diverse character. A subsidiary peak at ca. $850 \mathrm{Ma}$ is skewed to the youngest concordant grains at ca. $800 \mathrm{Ma}$, possibly documenting Pb-loss. The morphologically diverse nature of the ca. 890 Ma population suggests that the sedimentary protolith to the gt-bi schist was deposited after this time, but prior to development of the low $\mathrm{Th} / \mathrm{U}$ rims at $\leq 840 \mathrm{Ma}$ and intrusion of the tonalite (OM06-08) and gt-granite (OM06-07) at this location at ca. $835 \mathrm{Ma}$, which constrain its minimum depositional age.

OM06-07 garnet-bearing granite (unit JGG). Zircon from sample OM06-07 are light pink to yellowish-brown in colour, euhedral and have length/width ratios from 2 to 4 . CL images (Fig. 9a) show that grains are generally medium-bright with a limited range of internal textures including an unzoned or weakly zoned central region surrounded by a thin, weaklyzoned, medium to dark-CL outer mantle. Where zoning is present in the central portion, it generally continues without significant truncation into the outer mantle, suggesting that the latter represent a later stage in the same crystallization sequence rather than differently aged overgrowing rims. Unambiguous, inherited cores are absent. Fifteen analyses were performed on fourteen grains. $\mathrm{U}$ contents range from 134 to $2200 \mathrm{ppm}$ and $\mathrm{Th} / \mathrm{U}$ ratios from 0.04 to 0.84 , although Th concentrations show only small variations across the entire dataset (range $56-172 \mathrm{ppm}$ ). Both the highest $\mathrm{U}$ and lowest $\mathrm{Th} / \mathrm{U}$, which occur in CL-dark mantles, most 
likely represent late-stage $U$ enrichment in the host magma. Two analyses of CL-dark rims and one from the central part of a grain with very high common- $\mathrm{Pb}$ are significantly younger than the main group and likely to document Pb-loss; in addition, the oldest analysis obtained on a mixed rim/core is reversely discordant and possibly affected by a high-U matrix effect. After excluding these four analyses, eleven analyses combine to yield a concordia age (Fig. $9 \mathrm{a})$ of $832.0 \pm 4.8 \mathrm{Ma}(\mathrm{MSWD}=1.7)$. This is considered to approximate the crystallization age of the granite. The excess scatter revealed by the higher MSWD value may be explained by limited (but rather pervasive) $\mathrm{Pb}$-loss affecting the combined population; omission of two further young analyses results in an increased age of 834.4 \pm 4.9 Ma with a lower MSWD (1.4) and this is our preferred age.

OM06-08 tonalite (unit JGT). Zircon grains extracted from this tonalite are typically palepink to pale-brown in colour and euhedral, with length/width ratios between 2 and 6 though some acicular grains with aspect ratios as high as 10 occur. In CL (Fig. 9b), most grains are single-phase, homogeneous medium-bright, with weak oscillatory zoning towards their outer margin. CL dark cores are commonly structureless, but occasionally show weak zoning; truncated and/or rotated zoning relative to the rims is not observed. Twenty-one spot analyses were performed on fourteen grains. CL dark cores have U concentrations in the range $136-$ 900 ppm while the moderately bright CL rims and single-phase grains have lower U (34 to $106 \mathrm{ppm})$. The $\mathrm{Th} / \mathrm{U}$ ratios of the two phases are also different, though slightly overlapping, and range from $0.53-0.80$ and $0.41-0.67$. Despite the zoning obvious in CL and the subtle differences in U-Th chemistry, there is no clear correlation with age. All analyses are concordant within error (Fig. 9b) and all but one ${ }^{206} \mathrm{~Pb} /{ }^{238} \mathrm{U}$ age is in the range from $847 \mathrm{Ma}$ to $818 \mathrm{Ma}$; the outlier, which is attributed to Pb-loss, has an age of ca. 790 Ma. Notably, medium bright CL rims occur throughout the entire age spread, suggesting that the cores most likely represent an early magmatic phase within the same event that grew the cores, rather than inheritance with rims growing in a separate, later event. Omission of only the younger outlier from the entire dataset yields a concordia age of 832.7 $\pm 3.2 \mathrm{Ma}(\mathrm{MSWD}=1.3$ ), which is interpreted as the likely crystallization age of the tonalite. An alternative age interpretation is suggested by the spread and slightly skewed distribution of ages: six rims define an age of $823 \pm 6.5 \mathrm{Ma}(\mathrm{MSWD}=1.4)$ and possibly representing episodic $\mathrm{Pb}$ loss at this time, with the remaining fourteen analyses yielding a concordia age of 836.5 $\pm 3.3 \mathrm{Ma}(\mathrm{MSWD}=0.58$ ). 
Whole rock Sm-Nd data are plotted on a Nd isotope evolution diagram in Fig. 10. It should be noted that only these samples were considered suitably fresh for whole-rock analysis. $\mathrm{Nd}$ model ages have been calculated using the depleted mantle (DM) model of DePaolo et al. (1991). $\varepsilon_{\mathrm{Nd}}(\mathrm{t})$ values are calculated at the crystallization age inferred from the U-Pb zircon data for the magmatic and gneissic rocks and at the estimated maximum depositional age of the Al Wafi schist. The four analyses representing the older $(t>880 \mathrm{Ma})$ gneissic samples show a range in $\varepsilon_{\mathrm{Nd}}(\mathrm{t})$ from +3 to +6 , while those representative of the younger magmatic phase (ca. 820 to $840 \mathrm{Ma}$ ) range in $\varepsilon_{\mathrm{Nd}}(\mathrm{t})$ from +1.5 to +3 , and the two youngest granitoids $(\mathrm{t}$ $<760 \mathrm{Ma}$ ) have $\varepsilon_{\mathrm{Nd}}(\mathrm{t})$ from +1 to +2 . These values indicate a variable influence of older, evolved crust in most samples. Model ages range from $1020 \mathrm{Ma}$ to $1812 \mathrm{Ma}$, but these have to be treated with caution because of the possibility of mixing, magmatic fractionation of $\mathrm{Sm} / \mathrm{Nd}$ ratios and uncertainty over the relevant depleted mantle model. The single analysed sample of the Al Wafi schist has the lowest $\varepsilon_{\mathrm{Nd}}(\mathrm{t})$ value of -1.5 and a model age in excess of ca- 1600 Ma.

\section{Discussion}

\section{Geochronology and isotopic evolution the of Jebel Ja'alan and Qalhat inliers}

Our new U-Pb geochronology, summarized in figure 11, demonstrates that magmatism in the Jebel Ja'alan and Qalhat inliers started earlier than previously documented (Roger et al., 1991) with formation of the calc-alkaline dioritic to granodioritic precursors to the Ja'alan gneiss between ca. 905 to $890 \mathrm{Ma}$. Nd isotopes from the gneiss samples suggest a minor but not insignificant involvement of older crust in their source region, with a least contaminated $\varepsilon_{\mathrm{Nd}}(\sim 90)$ value of +6 ranging to more contaminated +3 . Rocks similar to the Al Wafi schist with $\varepsilon_{\mathrm{Nd}}(\sim 830)$ of -1.5 (Fig. 10) might provide such evolved $\mathrm{Nd}$ as a contaminant.

Meta-igneous rocks with a ca. 900 Ma protolith age were not sampled directly from the Qalhat inlier. However, a garnet-bearing pelitic gneiss contains a dominant ca. 890 Ma peak in detrital zircon ages, indicating potential local sedimentary recycling of similarly aged material, with older zircon ranging from >2560 Ma to 940 Ma. In the northern Jebel Ja'alan inlier, the Al Wafi schist also contains a wide range of detrital zircon ages, with age peaks at 1870 to $1620 \mathrm{Ma}$ and 920 to $850 \mathrm{Ma}$, the latter potentially also of local derivation. A granite sheet cross-cutting the Al Wafi schist may constrain its minimum depositional age to ca. 880 Ma but the presence of slightly younger zircon (>850 Ma) in the schist contradicts this unless 
(a) these represent $\mathrm{Pb}$-loss rather than true crystallization ages, or $(b)$ the small $(\mathrm{n}=3)$ zircon population used to date the granite sheet in fact represents inheritance from the schist.

A second magmatic phase at ca. 840 to $820 \mathrm{Ma}$ is recorded by tonalitic to granitic rocks of the Ja'alan batholith and likely correlatives in the Qalhat inlier, and in the latter provides a minimum depositional age for the sedimentary protolith to the garnet-bearing gneiss. $\mathrm{Nd}$ isotopes show that these rocks are more evolved than the older Ja'alan gneisses, with $\varepsilon_{\mathrm{Nd}}(\sim 830)$ values ranging from +3 to +1.5 . This difference relative to the older gneisses cannot be explained simply by derivation of the Ja'alan batholith rocks from the Ja'alan gneisses and instead requires an increased older crustal component, or derivations from gneisses more contaminated than those sampled. Despite this requirement for older crust, none of the Ja'alan batholith and related ca. 830 Ma granitoids yielded inherited zircon; although it cannot be discounted that these are present as a minor component which has eluded analysis, it is also possible that any inherited zircon has dissolved in the tonalitic to granodioritic melts (e.g. Watson and Harrison, 1983) and/or the actual contaminant was itself zircon poor and/or very fine-grained. The ca. 830 to $820 \mathrm{Ma}$ ages recorded by zircon rims in two of the analysed Ja'alan gneiss samples suggest an episode of metamorphism and migmatisation occurring synchronously with the later stages of the Ja'alan batholith intrusion. A final magmatic event in the region is recorded by dyke intrusion, dated here to ca. $760 \mathrm{Ma}$ on a granite porphyry. A slightly younger episode of granitic magmatism may be present but did not yield a robust age.

\section{Regional correlations and significance}

While the geographic isolation of the eastern Oman inliers complicates correlations with other parts of the Precambrian basement in Arabia, some broad tectonic implications may be inferred by comparison of ages (Fig. 11) and isotope characteristics (Fig. 10) with the Marbat region of southern Oman and the Arabian Shield of Saudi Arabia. The ca. 900 Ma Ja'alan gneiss represents the oldest, relatively juvenile arc magmatic rocks identified in the Arabian peninsula to date and likely relates to early stages of the closure of the Mozambique Ocean that resulted in the amalgamation of east and west Gondwana. Assuming a roughly northsouth orientation of the closing ocean (present-day coordinates), similar to that inferred from the exposed Arabian Shield, places the Ja'alan and Qalhat inliers structurally to the east of the Marbat region. In Marbat the gneiss protolith ages are between ca. 860 and $820 \mathrm{Ma}$ (Mercolli et al., 2006; Rantakokko et al., 2014) and similar ages have also been reported from the island 
of Socotra, Yemen, which was originally located close to the Marbat region before opening of the Gulf of Aden (Denèle et al., 2012; Whitehouse et al., 2012;). These ages are younger than the oldest arc rocks of the Ja'alan and Qalhat inliers, though roughly synchronous with emplacement of the Ja'alan batholith and migmatisation of the Ja'alan gneiss. This relative age difference is consistent with successive westward development of arc rocks on the eastern margin of a closing Mozambique Ocean.

As noted by Rantakokko et al. (2014), correlation of the eastern Arabian inliers in Oman with the exposed Arabian Shield is, at best, tentative given the extensive area of eastern Arabia that lacks exposed Precambrian basement. At ca. 900 to 820 Ma, the major phases of magmatism are older than both the juvenile Western Arc Terranes (< ca. $800 \mathrm{Ma}$ ) and the potentially slightly contaminated (Stoeser and Frost, 2006) Eastern Arc Terranes (<750 Ma), indicating that subduction and related arc magmatism was already well-established in the eastern Mozambique Ocean prior to generation of the arc rocks that make up much of the Arabian Shield. A notable exception to this are Neorchean to Paleoproterozoic gneissic terranes exposed in the easternmost Arabian Shield in Saudi Arabia and terranes identified in Yemen (Agar et al., 1992; Whitehouse et al., 1998, 2001a,b; Windley et al, 1996), which likely represent continental fragments introduced by lateral tectonics. While lack of basement exposure across much of eastern Arabia remains a major impediment to constructing a detailed terrane accretion history, the range of detrital zircon ages from ca. 900 to $820 \mathrm{Ma}$ obtained from fragments of basement sampled by salt domes in the UAE and Oman (Thomas et al., 2015) as well as from the Ediacaran Huqf Supergroup of Oman (Rieu et al., 2007) may be sourced more locally. This suggests an easterly source from contemporaneously exposed basement now represented by the Ja'alan and Qalhat inliers may complement a more distal, westerly source (e.g., Thomas et al., 2015; see their Fig 14).

Intriguingly, despite a significant difference in age, the initial $\mathrm{Nd}$ isotope systematics of the Ja'alan gneisses (Fig, 10) share closer affinity to the Eastern Arc Terranes than they do to the Western Arc Terranes that are closer in age. Stoeser and Frost (2006) attributed this difference in the Arabian Shield to either increased crustal contamination in the EAT, which has lower $\varepsilon_{\mathrm{Nd}}(\mathrm{t})$ than the WAT, a different (less depleted) mantle source, or a combination of both. While these options are entirely plausible for the Ja'alan gneisses as well, and our data are unable to distinguish unambiguously between them for the least evolved Ja'alan gneisses, the notably more evolved rocks of the Ja'alan batholith cannot readily be explained solely by a 
less depleted mantle and require input of a crustal contaminant. Additional evidence for such continental input comes from the $>900 \mathrm{Ma}$ detrital zircon population in the two paragneisses investigated here.

The Nd isotope systematics also strongly contrast to those reported from the <840 Ma rocks of the Marbat region of southern Oman, which are both uniform and juvenile, with a range in $\varepsilon_{\mathrm{Nd}}(\sim 840)$ between +5 and +7 (Fig. 10; Mercolli et al., 2006). Assuming that the Marbat region lies structurally to the west of the Ja'alan and Qalhat basement in an accreting arc scenario, this observation is consistent with successive outward growth from a continental margin and consequently diminishing continental input.

Given that the Arabian Shield is generally considered to be the northward extension of the East African Orogen formed by the collision between East and West Gondwana (Stern, 1994), the question arises as to the identity and nature of the eastern continent. Reconstructions of the assembled Gondwana continent (e.g. Kusky et al., 2003) locate eastern Oman close to the transition between an open ocean freeboard to the north and the continental blocks of central Iran and north-western India. This region has subsequently been complicated and obscured by the Cenozoic tectonics of the Arabian Sea region, formation of the Zagros orogenic belt and related thinned-skinned tectonics, and ophiolite obduction in eastern Oman (Glennie et al., 1973; Searle, 2007). Our contaminated magmatic arc rocks and detrital zircon populations a priori require an eastern continental block but its identity requires further study, of both the detrital zircons in the inliers and of their potential source regions.

\section{Conclusions}

The zircon U-Pb (SIMS) geochronology presented here constrains the crystallisation age of the Ja'alan gneisses to 900-880 Ma, which thus represent the oldest calc-alkaline magmatism in the Arabian peninsula that can be related to the Neoproterozoic closure of the Mozambique ocean. Neodymium isotopes in the Ja'alan gneisses, as well as pre-Neoproterozoic detrital zircon in metasediments from Ja'alan and Qalhat, demonstrate some contamination by evolved continental rocks. The Ja'alan gneisses were intruded by rocks of the Ja'alan batholith dated here to ca. 840- $820 \mathrm{Ma}$, which is contemporaneous with formation of metamorphic rims on zircon of the Ja'alan gneiss and is likely related to migmatisation and 
deformation of the latter. The Ja'alan batholith, together with two late ( $<760 \mathrm{Ma})$ granitic intrusions, also reveal contamination of their $\mathrm{Nd}$ isotopes by older evolved crust.

The crustal contamination seen in the Ja'alan and Qalhat rocks is in marked contrast to the uniformly juvenile Nd isotope signature recorded in the Marbat region of southern Oman. This suggests that the ca. $900 \mathrm{Ma}$ arc precursors of these easternmost inliers were emplaced in proximity to the eastern margin of the closing Mozambique Ocean, possibly in an Andean arc environment, although the location and identity of the continental edifice of East Gondwana is presently unconstrained. By the time the Marbat crystalline basement formed at $<840 \mathrm{Ma}$, continental influence had waned. This decrease, possibly due to outward growth of the arcs progressively further from continental influence, results in these inliers more closely resembling the juvenile arc terranes of the western Arabian Shield that record accretion on the opposite side of the Mozambique Ocean. The absence of any intact pre-Neoproterozoic components in these easternmost inliers of the Arabian peninsula further implies that the preNeoproterozoic terranes identified in Yemen and Saudi Arabia are isolated exotic continental blocks incorporated into the orogen.

\section{Acknowledgements}

Fanny Garel (ENS, Lyon), Kerstin Lindén, Hans Schöberg and Lev Ilyinsky (NRM) are thanked for analytical assistance. We also thank Ali Al-Rajhi and Mohammed Al Batashi from the Public Authority for Mining, Muscat, for their logistical support. Constructive reviews by Sobhi Nasir and two anonymous reviewers as well as editorial suggestions from Robert Stern considerably improved this manuscript and are gratefully acknowledged. This study was funded by a Swedish Research Council and Swedish Links (SIDA-MENA) grant to MJW and SAK. The PetroTectonics analytical facility is funded by the Knut and Alice Wallenberg Foundation and the NordSIMS ion microprobe facility operates as a joint Nordic infrastructure; this is NordSIMS publication 461.

\section{Disclosure statement}

The authors declare that they have no financial interest in or gain from the publication of this work.

\section{References}


Agar, R.A., Stacey, J.S., and Whitehouse, M.J., 1992, Evolution of the southern Afif Terrane - a geochronologic study. Saudi Arabian Directorate General of Mineral Resources. Open-File Report DGMR-OF-10-1541. 41 pp.

Denèle, Y., Leroy, S., Pelleter, E., Pik, R., Talbot, J. Y., and Khanbarri, K., 2012, The Cryogenian Arc formation and successive High-K calc-alkaline plutons of Socotra Island (Yemen). Arabian Journal of Geosciences 5, 903-924.

DePaolo, D.J., 1981, Nd isotopes in the the Colorado Front Range and crust-mantle evolution in the Proterozoic. Nature 291, 193-196.

DePaolo, D.J., A.M. Linn, and G. Schubert, 1991, The continental crustal age distribution: methods of determining mantle separation ages from $\mathrm{Sm}-\mathrm{Nd}$ isotopic data and application to the southwestern U.S. J. Geophys. Res. 96: 2071-2088.

Gass, I.G., Ries, A.C., Shackleton, R.M., and Smewing, J.D., 1990. Tectonics, geochronology and geochemistry of the Precambrian rocks of Oman. Geological Society, London, Special Publications, 49:585-599.

Goldstein, S.L., O’Nions, R.K., and Hamilton, P.J., 1984, A Sm-Nd isotopic study of atmospheric dusts and particulates from major river systems. Earth and Planetary Science Letters 70, 221- 236.

Jacobsen, S.B. and Wasserburg, G.J., 1980, Sm-Nd isotopic evolution of chondrites. Earth and Planetary Science Letters 50, 139-155.

Glennie, K.W., Boeuf, M.G.A., Hughes-Clarke, M.W., Moody-Stuart, M., Pilaar W.F.H., and Reinhardt, B.M., 1973, Late Cretaceous nappes in Oman Mountains and their geological evolution. American Association of Petroleum Geologists Bulletin 57, 5-27.

Glennie, K.W., Boeuf, M.G.A., Hughes-Clarke, M.W., Moody-Stuart, M., Pilaar W.F.H., and Reinhardt, B.M., 1974, Geology of the Oman Mountains. Verhandelingen Koninklijke Nederlands geologisch mijnbouw kundig Genootschap, no. 31, 423 p.

Kusky, T.M., Abdelsalam, M., Stern, R.J., and Tucker, R.D., 2003, Preface - Evolution of the East African and related orogens, and the assembly of Gondwana. Precambrian Research 123, 81-85. 
Ludwig, K.R., 1998, On the treatment of concordant uranium-lead ages. Geochimica et Cosmochimica Acta, 62, 665-676.

Ludwig, K.R., 2004, User's Manual for Isoplot, 3.16. A geochronological toolkit for Microsoft Excel. Berkeley Geochronology Center Special Publication, No 4, 2455 Ridge Road, Berkeley CA, USA.

Lugmair, G. W., and Marti, K., 1978, Lunar initial ${ }^{143} \mathrm{Nd} /{ }^{144} \mathrm{Nd}$ : differential evolution of the lunar crust and mantle. Earth and Planetary Science Letters 39, 349-357.

McWilliams, M.O., 1981, Palaeomagnetism and Precambrian tectonic evolution of Gondwana. In Precambrian Plate Tectonics, ed. A Kroner, pp. 649-87. Amsterdam:Elsevier

Mercolli, I., Briner, A. P., Frei, R., Schönberg, R., Nägler, T. F., Kramers, J., and Peters,T., 2006, Lithostratigraphy and geochronology of the Neoproterozoic crystalline basement of Salalah, Dhofar, Sultanate of Oman. Precambrian Research, 145, 182-206.

Rantakokko, N.E., Whitehouse, M.J., Pease, V., and Windley, B.F., 2014, Neoproterozoic evolution of the eastern Arabian basement based on a refined geochronology of the Marbat region, Sultanate of Oman. Geological Society, London, Special Publications, $392,1-7$.

Rieu, R., Allen, P.A., Cozzi, A., Kosler, J., and Bussy, F., 2007, A composite stratigraphy forthe Neoproterozoic Huqf Supergroup of Oman: integrating new litho-, chemo-and chronostratigraphic data of the Mirbat area, southern Oman. Journal of the Geological Society $164,997-1009$.

Roger, J., Bechennec, F., Janjou, D., Le Metour, J., Wyns, R., and Beurrier, M., 1991, Geological Map of Ja'alan, Sheet NF 40-8 E, 1-100 000. Directorate General of Minerals, Oman Ministry of Petroleum and Minerals.

Rollinson, H.R., Searle, M.P., Abbasi, I.A., Al-Lazki, A.I., and Al-Kindi, M.H., 2014, Tectonic evolution of the Oman Mountains: an introdution. Geological Society, London, Special Publications, 392, 107-127. 
Searle, M.P., 2007. Structural geometry, style and timing of deformation in the Hawasina Window, Al Jabal al Akhdar and Saih Hatat culminations, Oman Mountains. GeoArabia 12, 99-130.

Stacey, J.S., and Kramers, J.D., 1975, Approximation of terrestrial lead isotope evolution by a two-stage model. Earth and Planetary Science Letters, 26, 207-221.

Steiger, R.H., and Jäger, E., 1977. Subcommission on geochronology: convention of the use of decay constants in geo-and cosmochronology. Earth and Planetary Science Letters, 26, 359-362.

Stern, R.J., 1994, Neoproterozoic (900-550 Ma) Arc Assembly and continental collision in the East African Orogen. Annual Review of Earth and Planetary Sciences, 22, 319-351.

Stoeser, D.B., and Frost, C.D., 2006. Nd, Pb, Sr, and O isotopic characterization of Saudi Arabian Shield terranes. Chemical Geology, 226, 163-188.

Thomas, R.J., Ellison, R.A., Goodenough, K.M., Roberts, K.M., and Allen, P.A., 2015, Salt domes of the UAE and Oman: Probing eastern Arabia. Precambrian Research 256, 1-16.

Watson, E.B., and Harrison, T.M., 1983, Zircon saturation revisited: temperature and composition effects in a variety of crustal magma types. Earth and Planetary Science Letters 64, 295-304

Whitehouse, M.J., Windley, B.F., Ba-Bttat, M.A.O., Fanning, C.M., and Rex, D.C., 1998, Crustal evolution and terrane correlation in the eastern Arabian Shield, Yemen: geochronological constraints. Journal of the Geological Society, London, 155, 281-295.

Whitehouse, M.J., Stoeser, D.B., and Stacey, J.S., 2001a, The Khida terrane geochronological and isotopic evidence for Paleoproterozoic and Archaen crust in the eastern Arabian Shield of Saudi Arabia. Gondwana Research, 4, 200-202.

Whitehouse, M.J., Windley, B. F., Stoeser, D. B., Al-Khirbash, S., Ba-Bttat, M.A.O., and Haider A., 2001b, Precambrian basement character of Yemen and correlations with Saudi Arabia and Somalia. Precambrian Research 105, 357-369.

Whitehouse, M., Al-Khirbash, S., and Pease, V, 2012, A geochronological investigation of the Precambrian basement of Socotra, Yemen. International Conference on the Geology 
of the Arabian Plate and the Oman Mountains, 7-9 ${ }^{\text {th }}$ January, 2012, Sultan Qaboos University, Muscat, Oman. GeoArabia 17(3).

Whitehouse, M. J., and Kamber, B. S., 2005, Assigning dates to thin gneissic veins in highgrade metamorphic terranes - a cautionary tale from Akilia, southwest Greenland: Journal of Petrology, v. 46, p. 291-318.

Whitehouse, M.J., Kamber, B.S., and Moorbath, S., 1999, Age significance of U-Th_Pb zircon data from early Archaean rocks of west Greenland - a reassessment based on combined ion-microprobe and imaging studies. Chemical Geology, 160, 201-224.

Wiedenbeck, M., Allé, P., Corfu, F., Griffin, W.L., Meier, M., Oberli, F., von Quadt, A., Roddick, J.C., and Spiegel, W., 1995, Three natural zircon standards for U-Th-Pb, LuHf, trace element and REE analyses. Geostandards Newsletter, 19, 1-23.

Windley, B.F., Whitehouse, M.J., and Ba-Bttat, M.A.O., 1996, Early Precambrian gneiss terranes and Pan-African island arcs in Yemen: crustal accretion of the eastern Arabian Shield. Geology 24, 131-134.

Würsten, F., Flisch, M., Michalski, I., Le Métour, J., Mercolli, I., Matthäus, U., and Peters,T., 1991, The uplift history of the Precambrian crystalline basement of the Jabal J'alan (Sur, Area). In: Peters, T., Nicolas, A., Coleman, R.G., (Eds.), Ophiolite Genesis and Evolution of the Oceanic Lithosphere, 1991. Dordrecht, pp. 613-626.

Wyns, R., Bechennec, F., Le Metour, J., and Roger, J., 1992, Geological Map of Tiwi, Sheet NF 40-8 B, scale 1:100,000. Directorate General of Minerals, Oman Ministry of Petroleum and Minerals.

Yeshanew, F.G., Pease, V., Whitehouse, M.J., and Al-Khirbash, S., 2015, Zircon U-Pb geochronology and $\mathrm{Nd}$ isotope systematics of the Abas terrane, Yemen: Implications for Neoproterozoic crust reworking events. Precambrian Research 267, 106-120. 


\section{Figure captions}

Figure 1. Geological setting of the two study areas. A) Regional setting B) Simplified geology of Jebel Ja'alan with sample locations. C) Simplified geology of the Qalhat area with sample locations. Note that the geological legend is the same for both areas and follows the units established by Roger et al. (1991) for the Ja'alan region.

Figure 2. Field characteristics of the Ja'alan and Qalhat inliers: a) Ja'alan banded gneiss (JG unit) with amphibolite pod, Jebel Ja'alan east; b) Ja'alan banded grey gneiss (JG unit, sample OM06-03), Jebel Ja'alan east; c) Ja'alan migmatitic gneiss (JG unit, sample OM06-02), Jebel Ja'alan east; d) coarse amphibolite of the Ja'alan gneiss (JGA unit, sample OM06-05), Jebel Ja'alan east; e) Al Wafi mica schist (unit WM, sample OM0541) cut by granite sheet (unit GR, sample OM05-41), Jebel Ja'alan north; f) garnetbearing metapelitic gneiss (JG unit, sample OM06-06), Qalhat - scale bar is $0.5 \mathrm{~m}$; g) Ja'alan batholith tonalite-granodiorite (TG) with xenoliths of Ja'alan gneiss (JG) and amphibolite (JGA) visible, Jebel Ja'alan east; h) Ja'alan batholith granite (JGG unit) with banded gneiss (JG) xenolith, Jebel Ja'alan east; i) Granodiorite of Ja'alan batholith (unit JGT, sample OM05-47) with mingling enclaves of diorite, Jebel Ja'alan south;j) garnet-granite (JGG unit, sample OM06-07) with metapelitic schlieren, Qalhat.

Figure 3. A) Total Alkali versus Silica (after LeMaitre et al, 1989). The samples represent subalkaline compositions typical of subduction-related arcs. B) Normative feldspar mineralogy classification (after Barker, 1979). The samples represent tonalitetrondhjemite-granodiorites. In both figures the Ja'alan gneiss samples represent amphibolitic (JGA) and felsic (JG) compositional phases.

Figure 4. Inverse (Tera-Wasserburg) concordia diagrams $\left({ }^{207} \mathrm{~Pb} /{ }^{206} \mathrm{~Pb}\right.$ vs. $\left.{ }^{238} \mathrm{U} /{ }^{206} \mathrm{~Pb}\right)$ and cathodoluminescence (CL) images of selected grains from samples a) OM05-40, b) OM05-41, and c) OM05-45. Grain numbers and where appropriate, spot designation, correspond to Table S2. Where concordia ages have been calculated, the uncertainty is shown at the $2 \sigma / 95 \%$ confidence level and the MSWD is that of combined concordance and equivalence. Analyses included in the concordia age are shaded, with the Concordia age ellipse shaded in dark tone. Omitted samples are shown as dashed ellipses.

Figure 5. Inverse concordia diagrams and CL images of selected grains from samples: a) OM05-46, b) OM05-47, and c) OM05-48. Annotation details as for Figure 4. 
Figure 6. Inverse concordia diagrams and CL images of selected grains from samples: a) OM06-01, b) OM06-02, and c) OM06-03. Annotation details as for Figure 4.

Figure 7. Inverse concordia diagrams and CL images of selected grains from samples: a) OM06-04, and b) OM06-05. Annotation details as for Figure 4.

Figure 8. Inverse concordia diagrams and CL images of selected grains from sample OM0606. Annotation details as for Figure 4.

Figure 9. Inverse concordia diagrams and CL images of selected grains from samples: a) OM06-07, and b) OM06-08. Annotation details as for Figure 4. Note that unfilled ellipses with solid outline in (b) are included in the rim (R) concordia age.

Figure 10. Sm-Nd evolution diagram $\left(\varepsilon_{\mathrm{Nd}}(\mathrm{t})\right.$ vs. age) showing the evolution lines for Ja'alan and Qalhat inlier samples analysed in this study, with the symbol shown at the crystallization (dark symbol, “cryst” in legend for Ja'alan gneiss), metamorphism (pale symbol, "met" in legend for Ja'alan gneiss) or minimum depositional age determined from zircon $\mathrm{U}-\mathrm{Pb}$. From this age, the evolution line is dashed to its intersection with possible depleted mantle reservoirs (DeP91 - DePaolo et al., 1991; DeP81 - DePaolo, 1981; G84 - Goldstein et al., 1984). Shaded fields shown for comparison represent the range of age and $\varepsilon_{\mathrm{Nd}}(\mathrm{t})$ in rocks of the Western Arc Terranes (WAT) and Eastern Arc Terranes (EAT) of the Saudi Arabian Shield (data from Stoeser and Frost, 2006) and the Salalah-Marbat Precambrian inlier of southern Oman (S-M) data from Mercolli et al., 2006).

Figure 11. Summary of ages obtained from samples in this study (sample numbers are abbreviated by omitting prefix OM05 or OM06) compared with those of the Marbat inlier (Rantakokko et al., 2014) and the arc terranes (abbreviations as in Table 1) of the Saudi Arabian Shield (Stoeser and Frost, 2006). Where two ages have been obtained from a single sample " $\mathrm{C}$ " denotes the age from zircon cores (likely crystallization) while "R" denotes the age of zircon rims (likely metamorphism). 
Table 1. Summary of Jebel Ja'alan and Qalhat samples.

Table 2. Sm-Nd data from Jebel Ja'alan and Qalhat samples.

Supplementary material

Table S1. Major element geochemistry for Jebel Ja'alan and Qalhat samples.

Table S2. U-Th-Pb SIMS analytical results.

Supplemental references

Barker, F., 1979. Trondhjemite: Definition, environment and hypotheses of origin. IN:

Barker F. (ed), Trondhjemites, Dacites, and Related Rocks. Elsevier, Amsterdam, pp. 1-12.

Le Maitre, R.W., Bateman, P., Dubek, A., Keller, J., Lameyre, J., Le Bas, M.J., Sabine, P.A., Schmid, R., Sorensen, H., Streckeisen, A., Woolley, A.R., Zanettin, B., 1989. A Classification of Igneous Rocks and Glossary of Terms: Recom-mendations of the International Union of Geological Sciences Subcommission on the Systematics of Igneous Rocks. Blackwell, Oxford, 193 pp. and Wall Chart. 

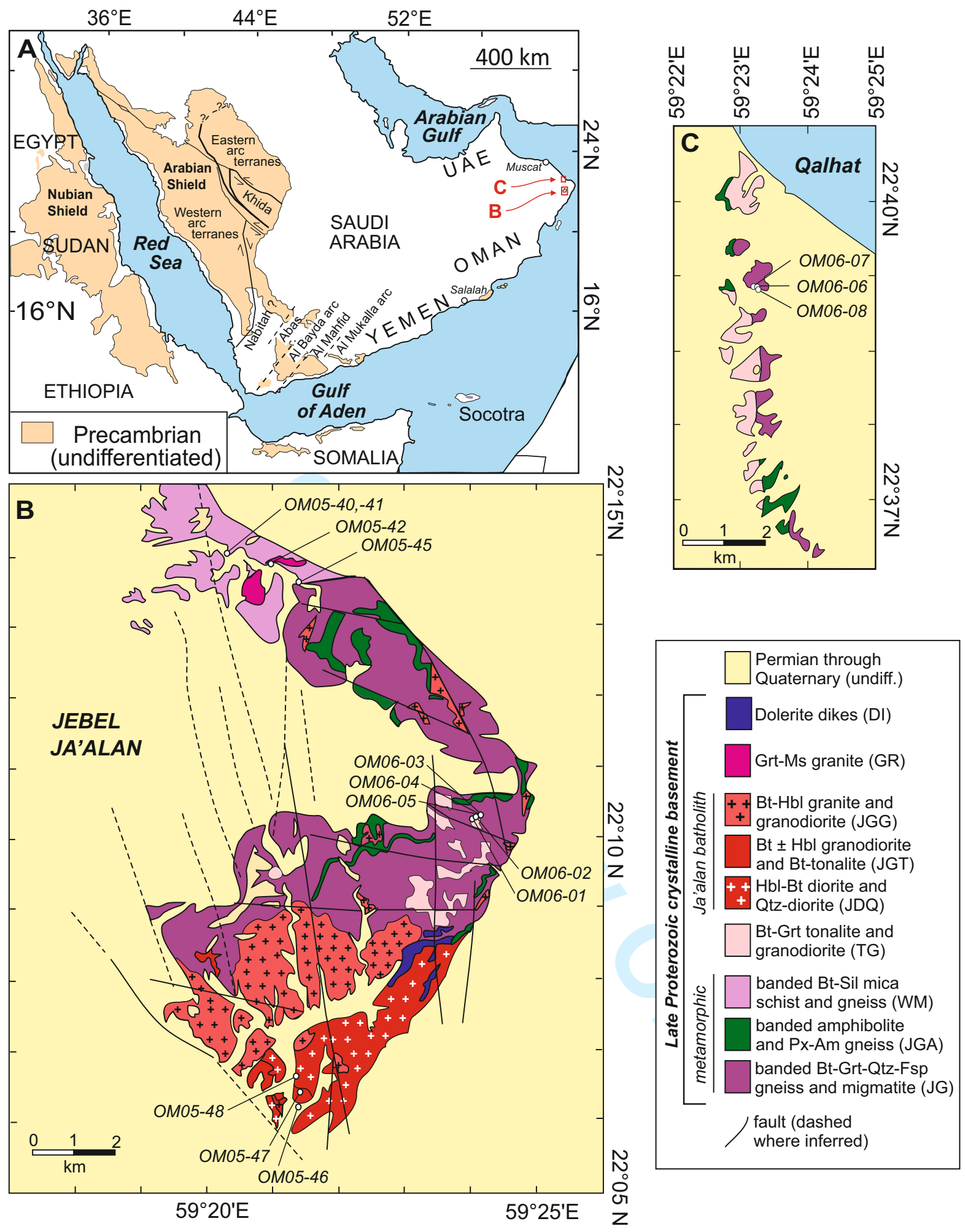

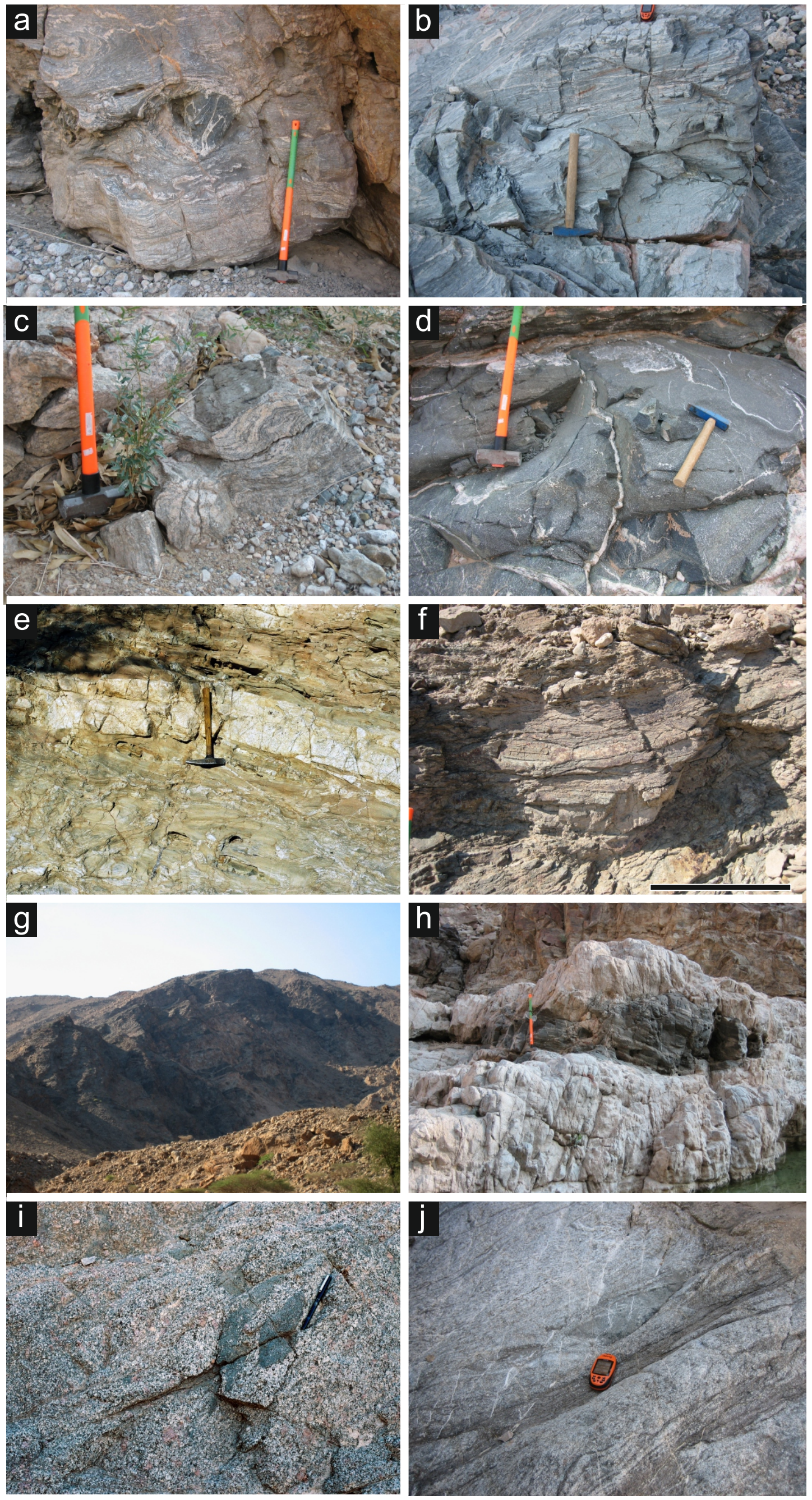

URL: https://mc.manuscriptcentral.com/tigr E-mail: rjstern@utdallas.edu

Whitehouse et al., Fig. 2 
A

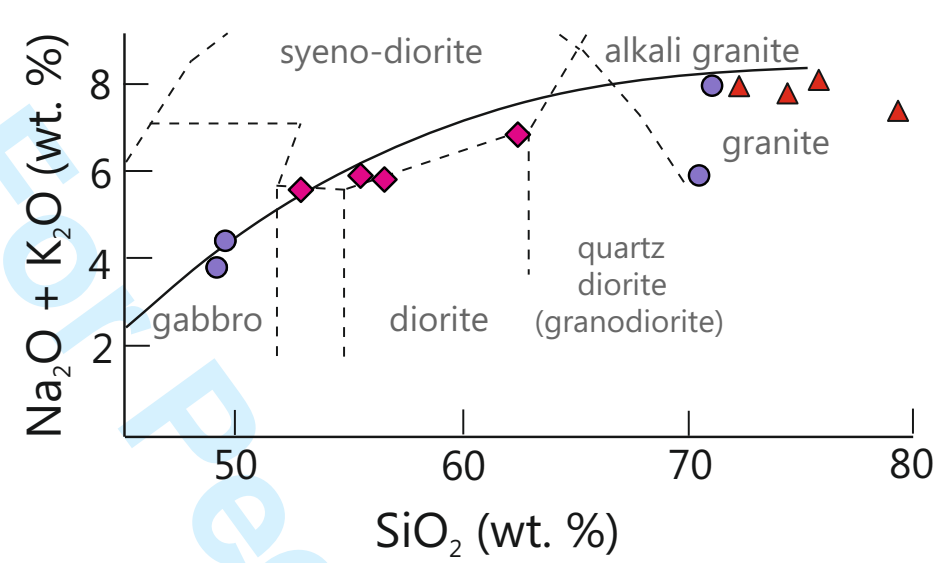

B

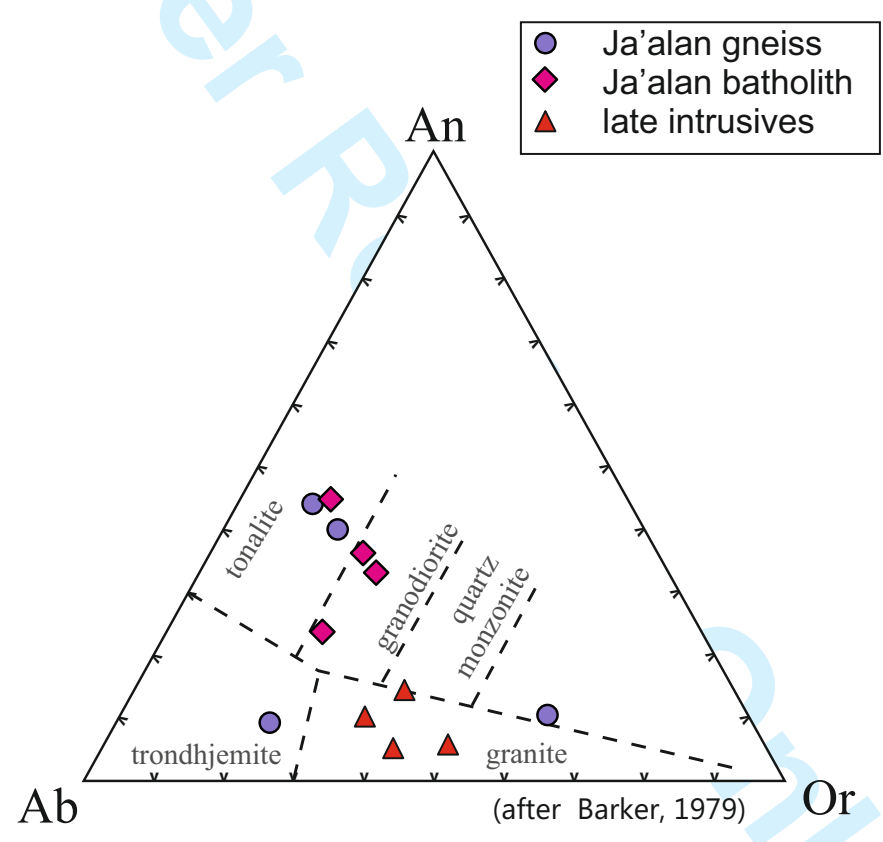

Whitehouse et al., Figure 3 


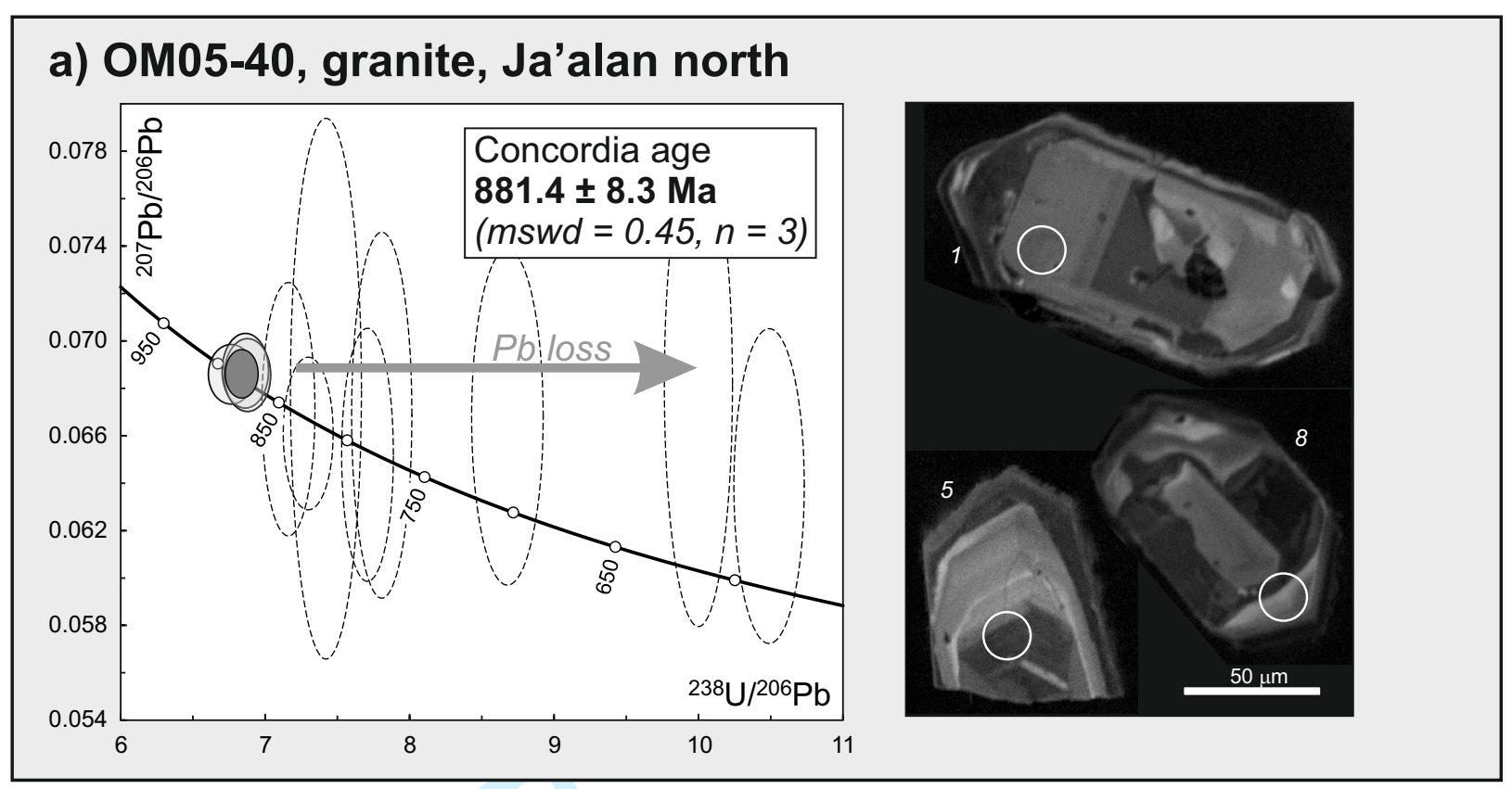

b) OM05-41, mica schist, Ja'alan north
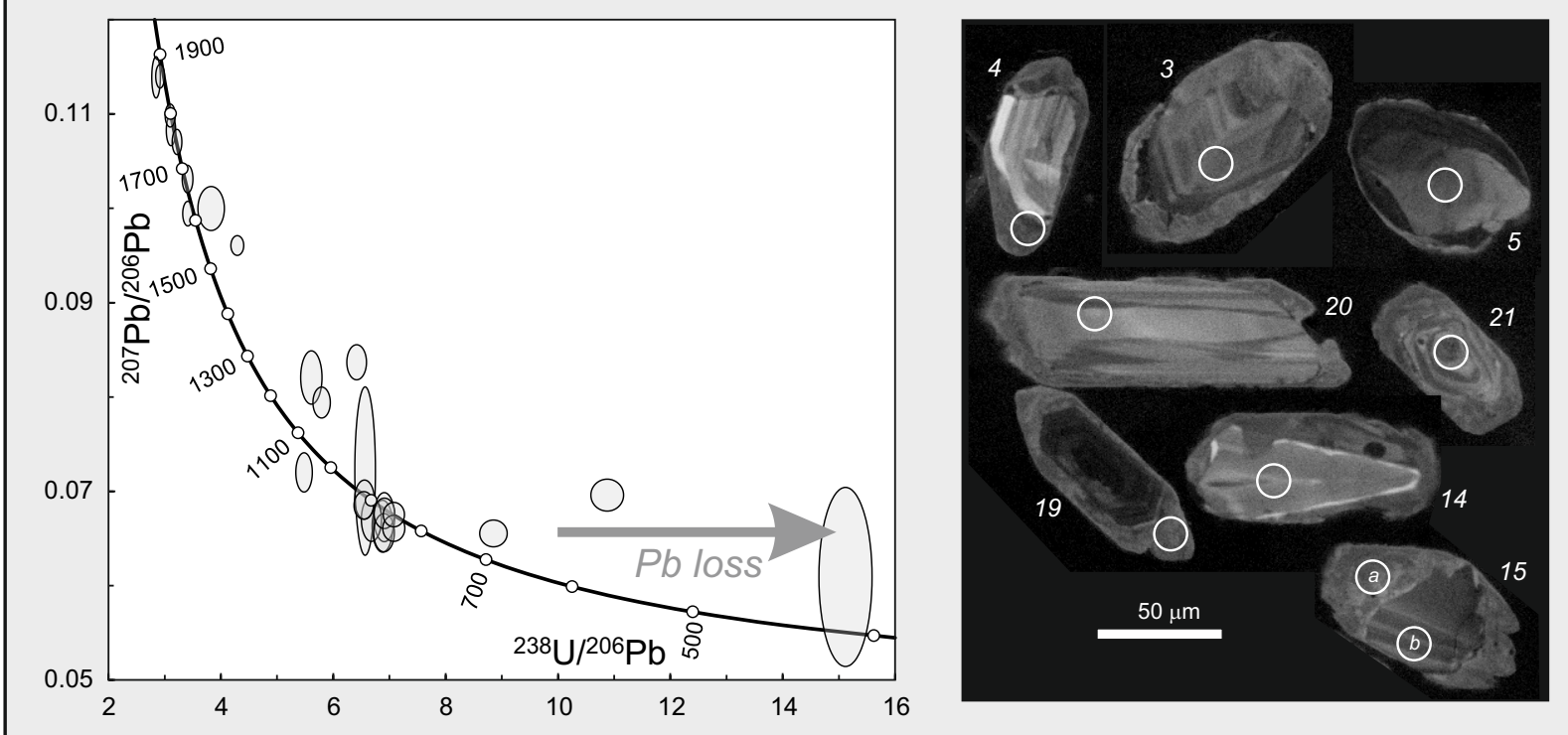

c) OM05-45, granodiorite, Ja'alan north
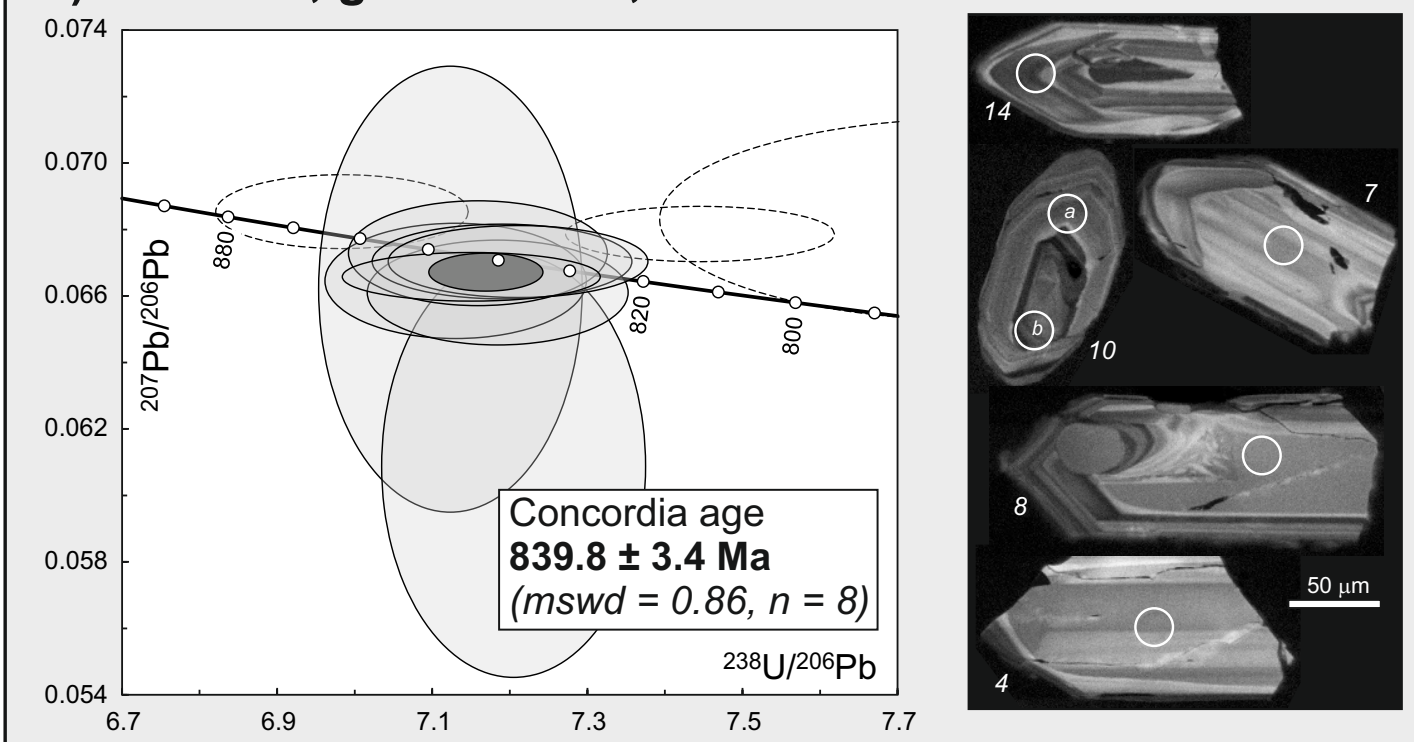

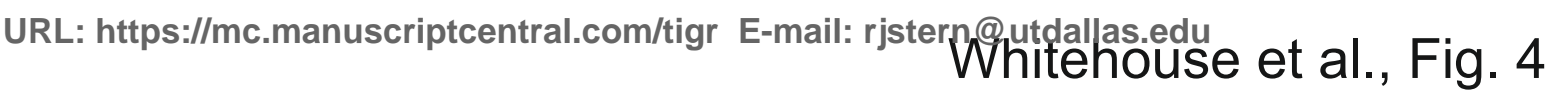




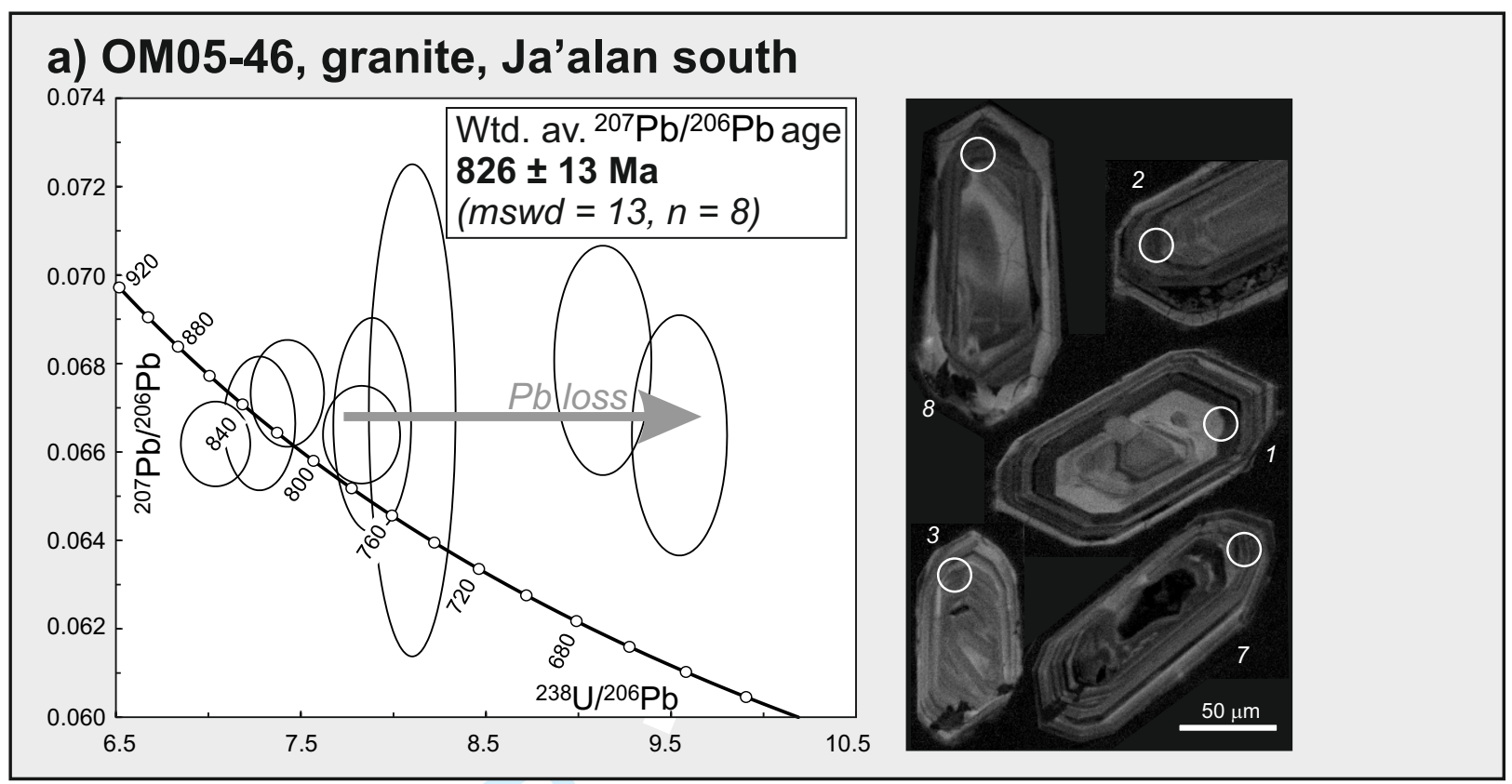

\section{b) OM05-47, granodiorite, Ja'alan south}
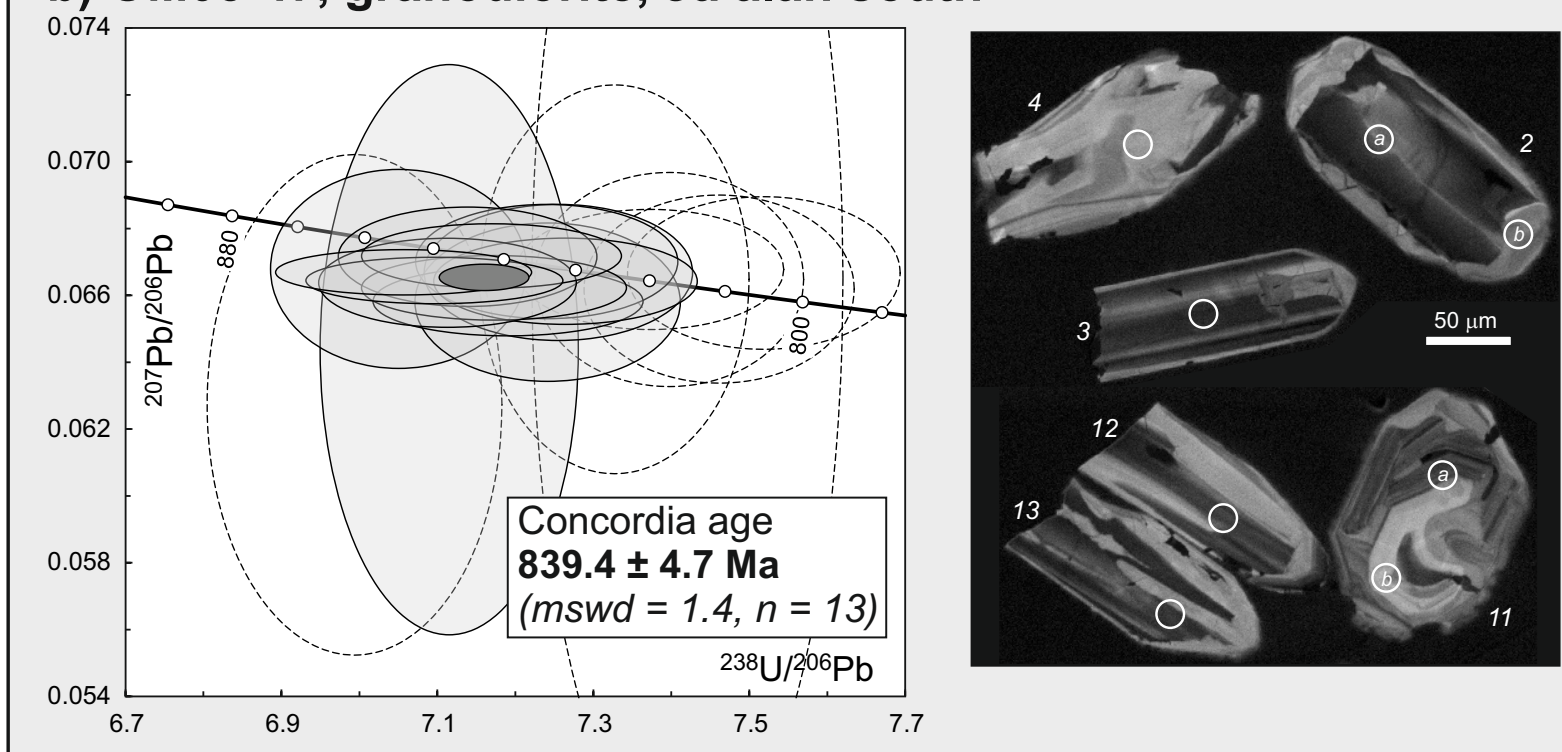

c) OM05-48, granite porphyry, Ja'alan south
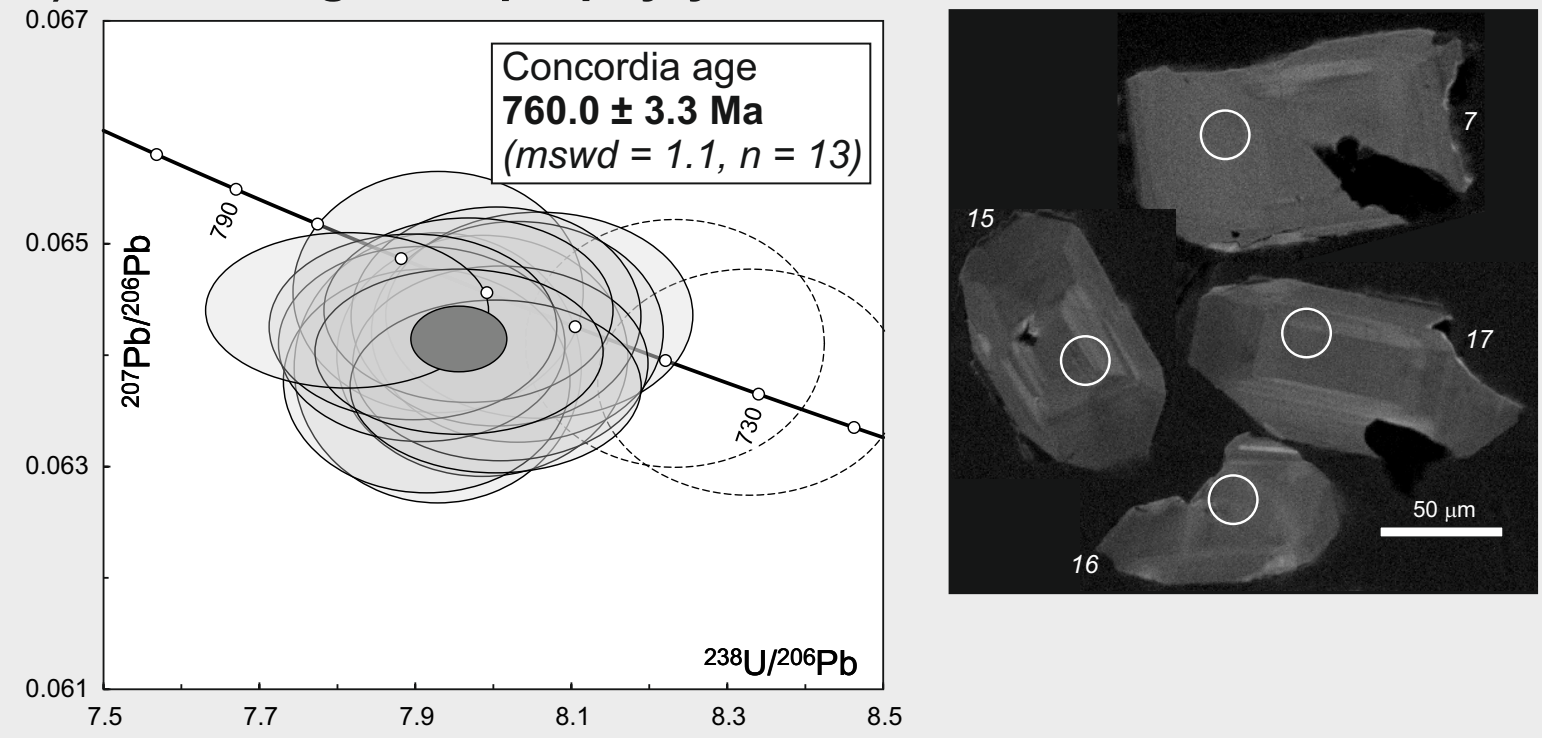

URL: https://mc.manuscriptcentral.com/tigr E-mail: rjstern@utdallas.edu 


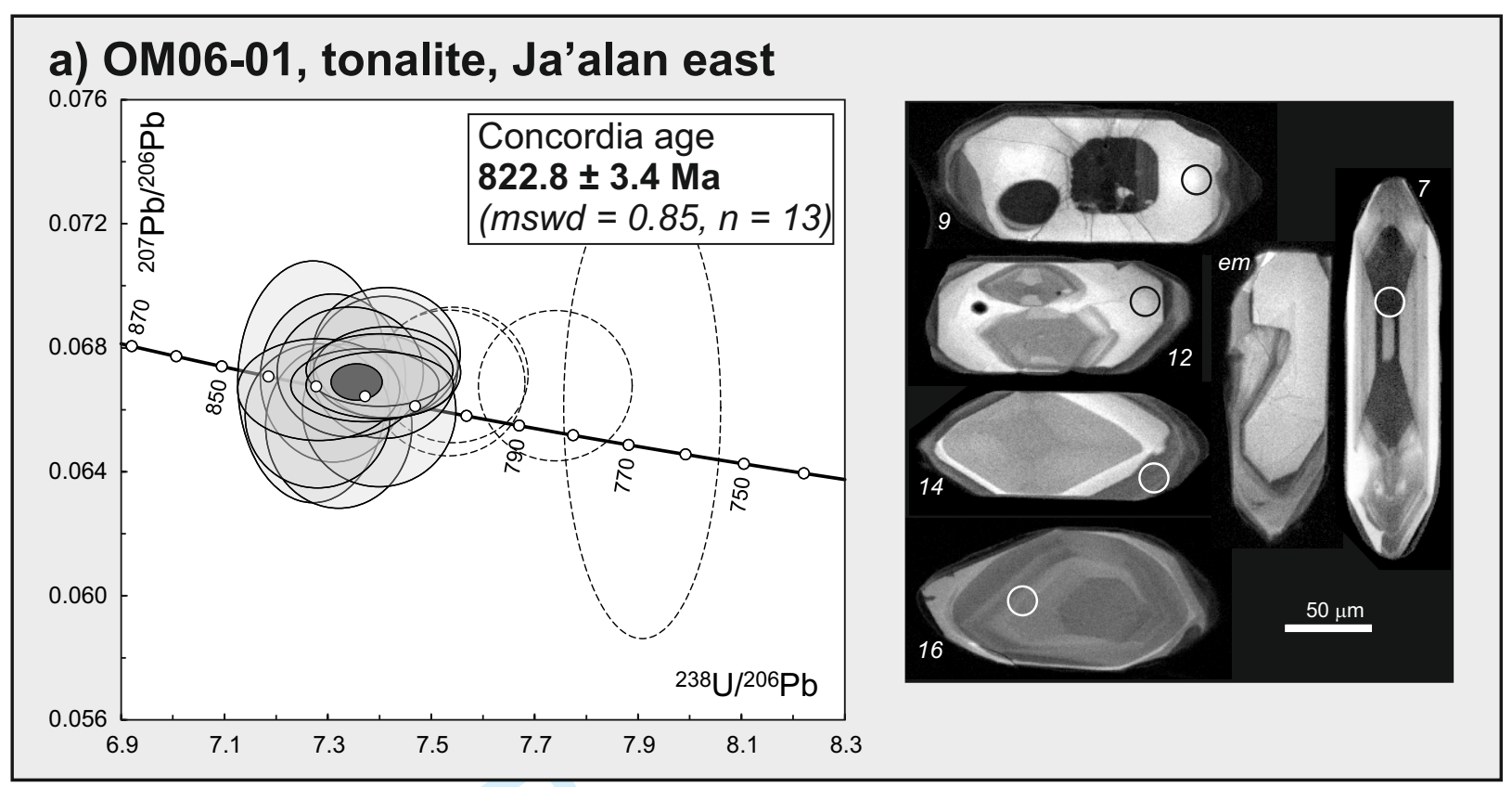

b) OM06-02, migmatitic gneiss, Ja'alan east
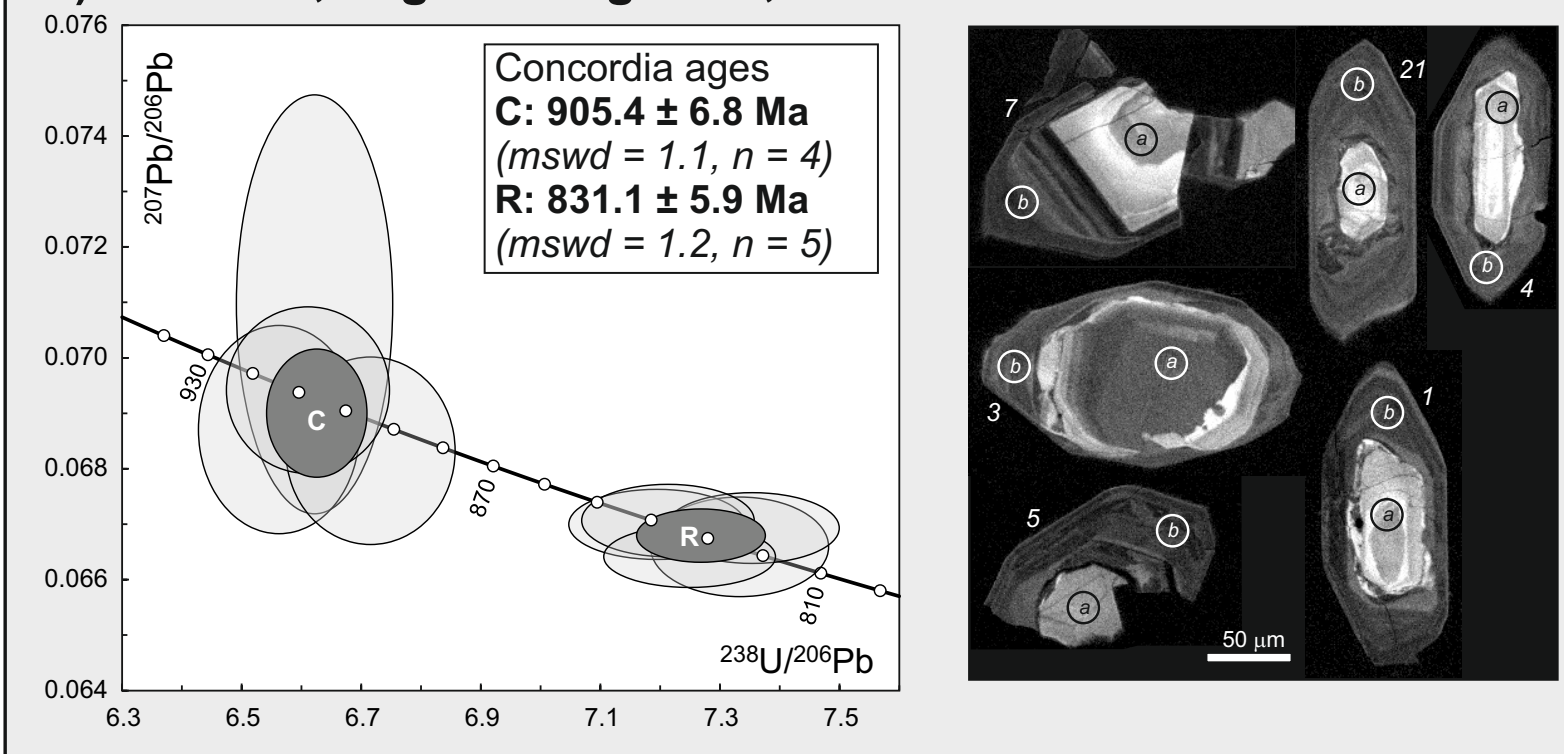

c) OM06-03, grey gneiss, Ja'alan east
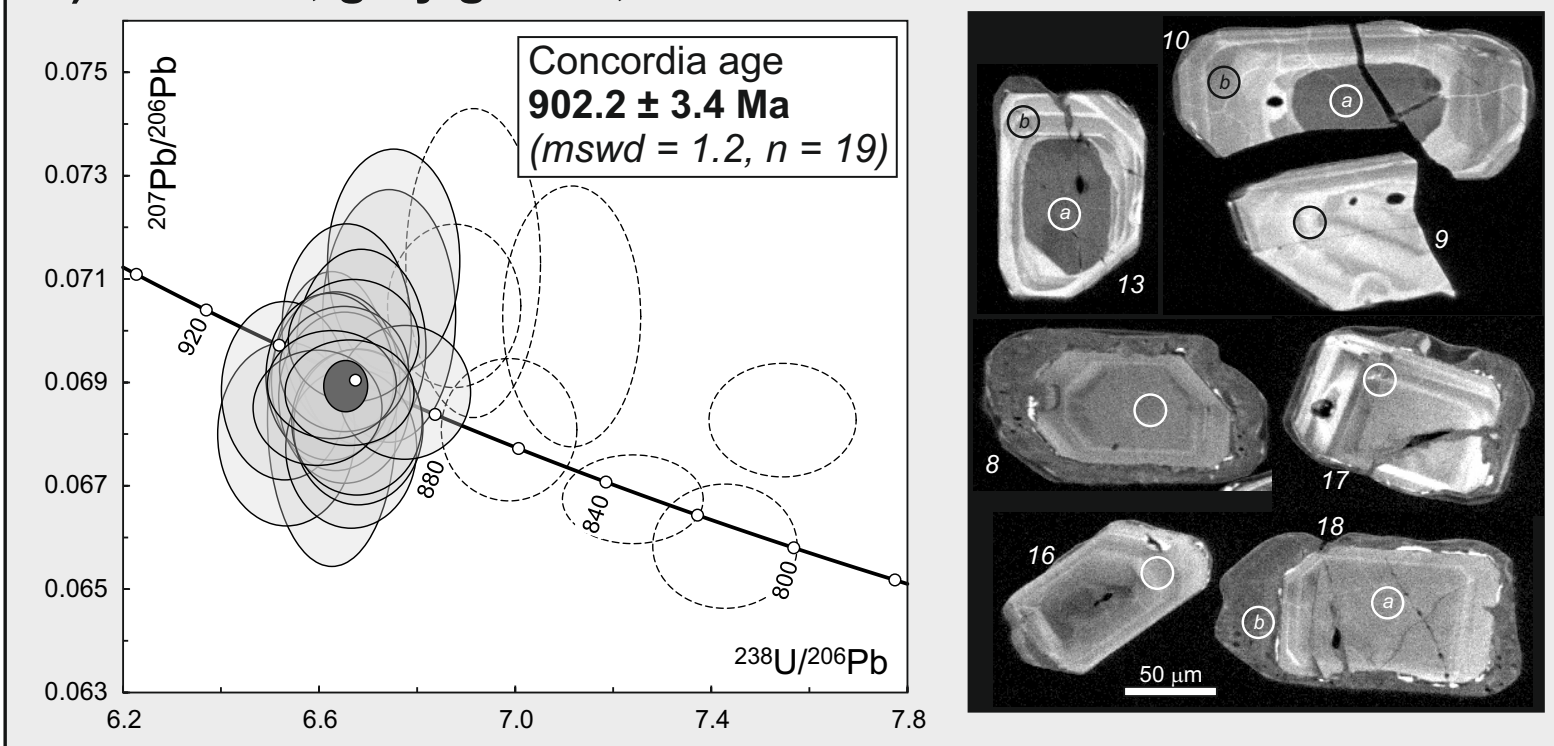

URL: https://mc.manuscriptcentral.com/tigr E-mail: rjstern@utdallas.edu 

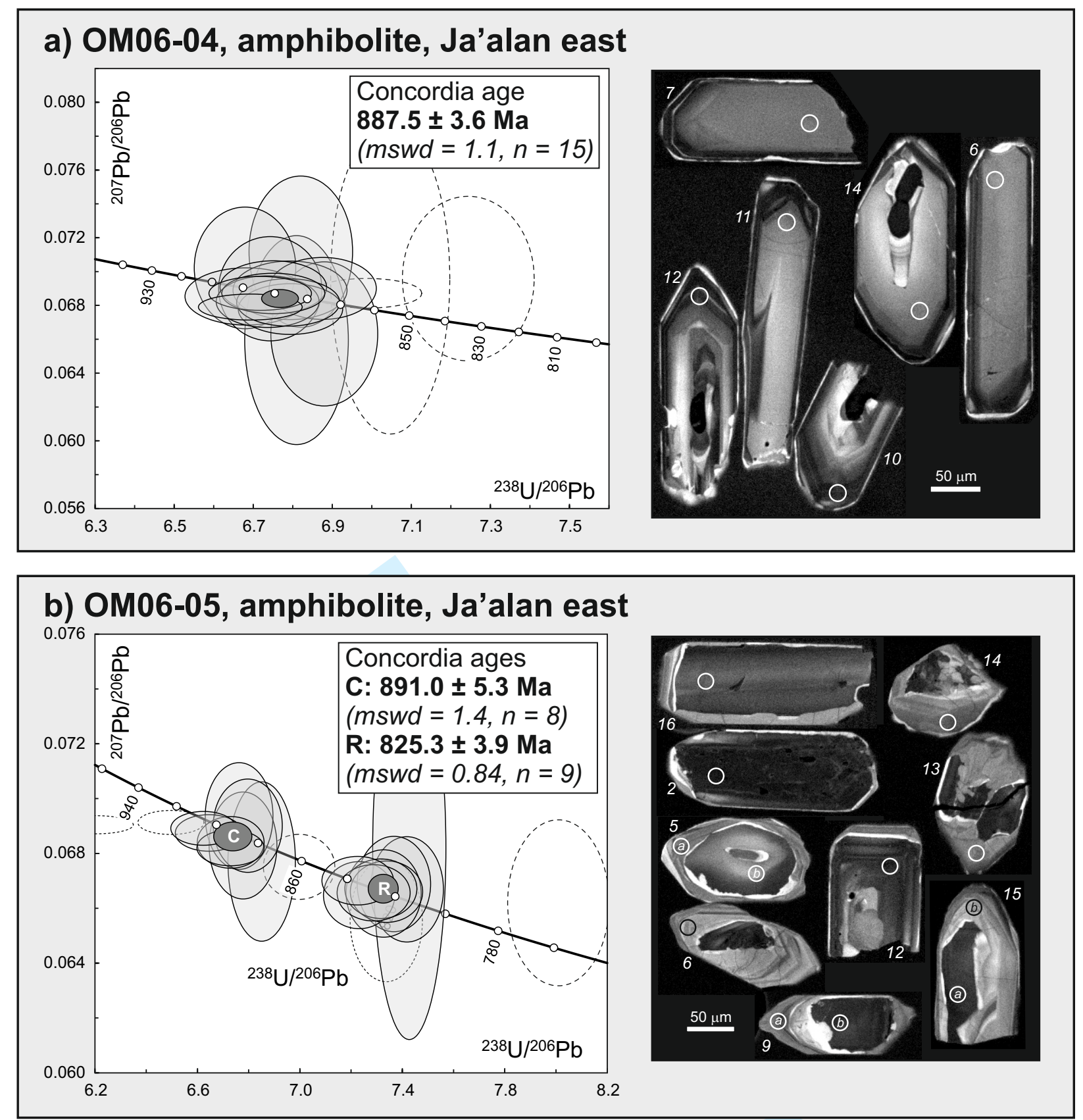


\section{OM06-06, gt-bi gneiss, Qalhat}
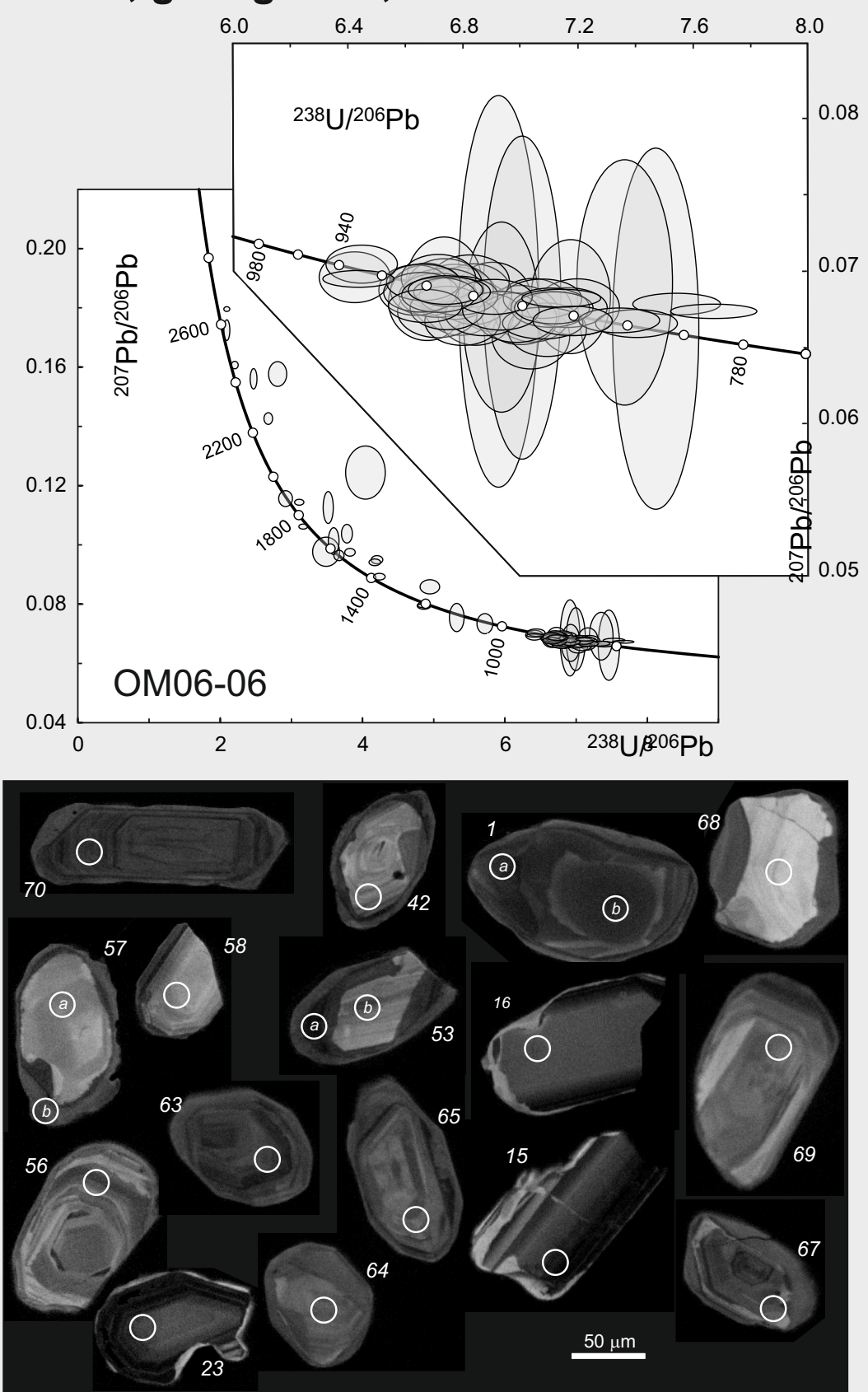


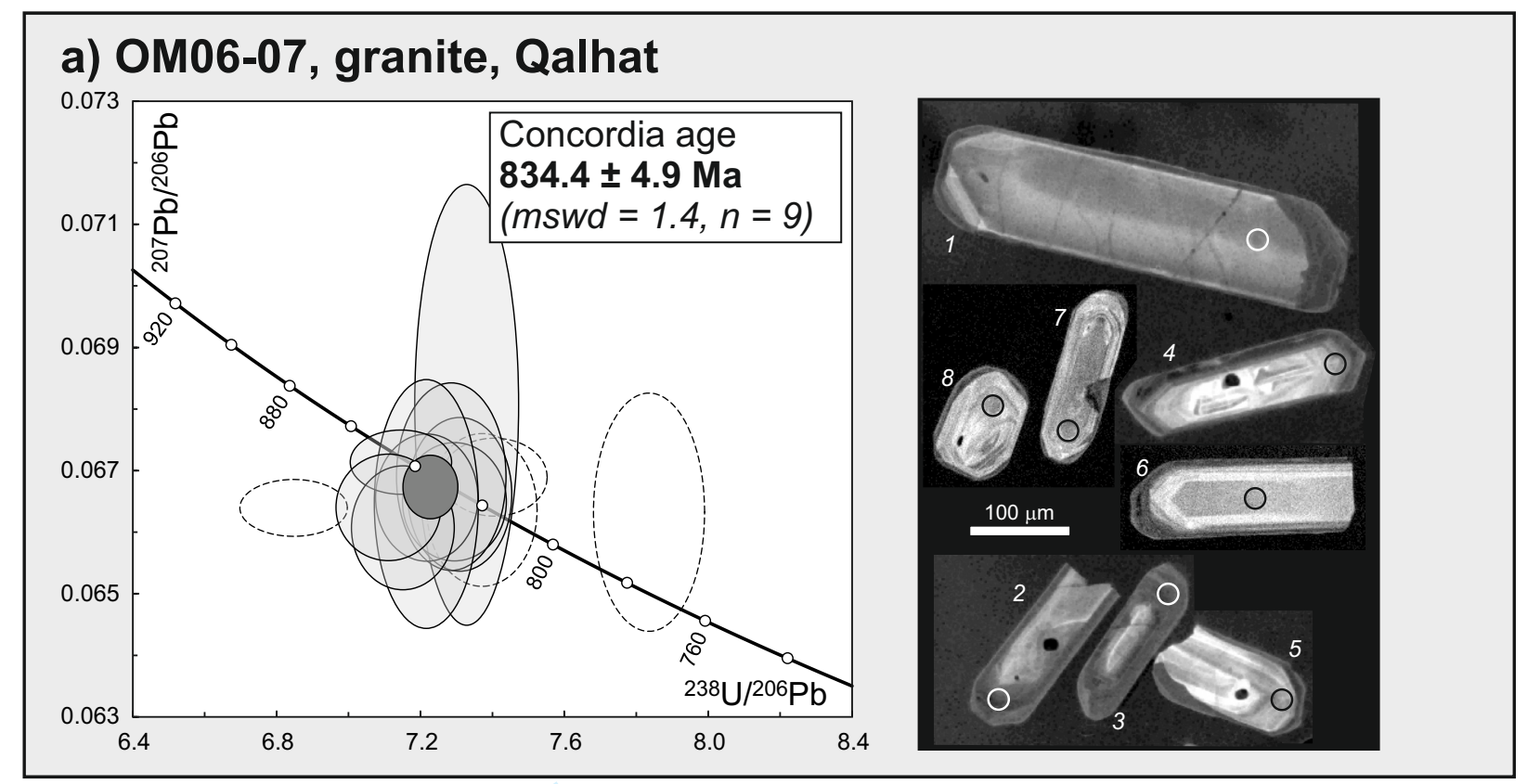

b) OM06-08, tonalite, Qalhat
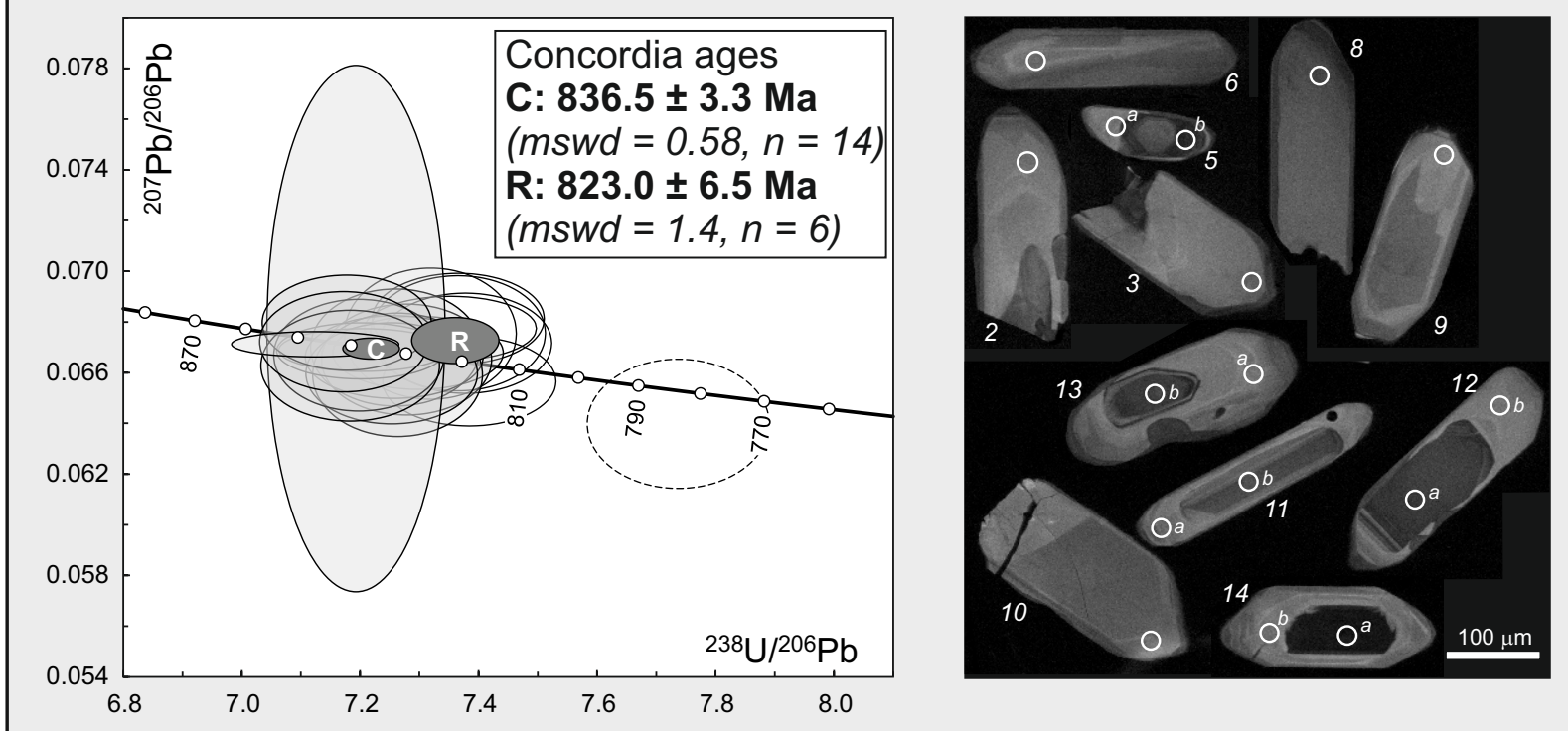


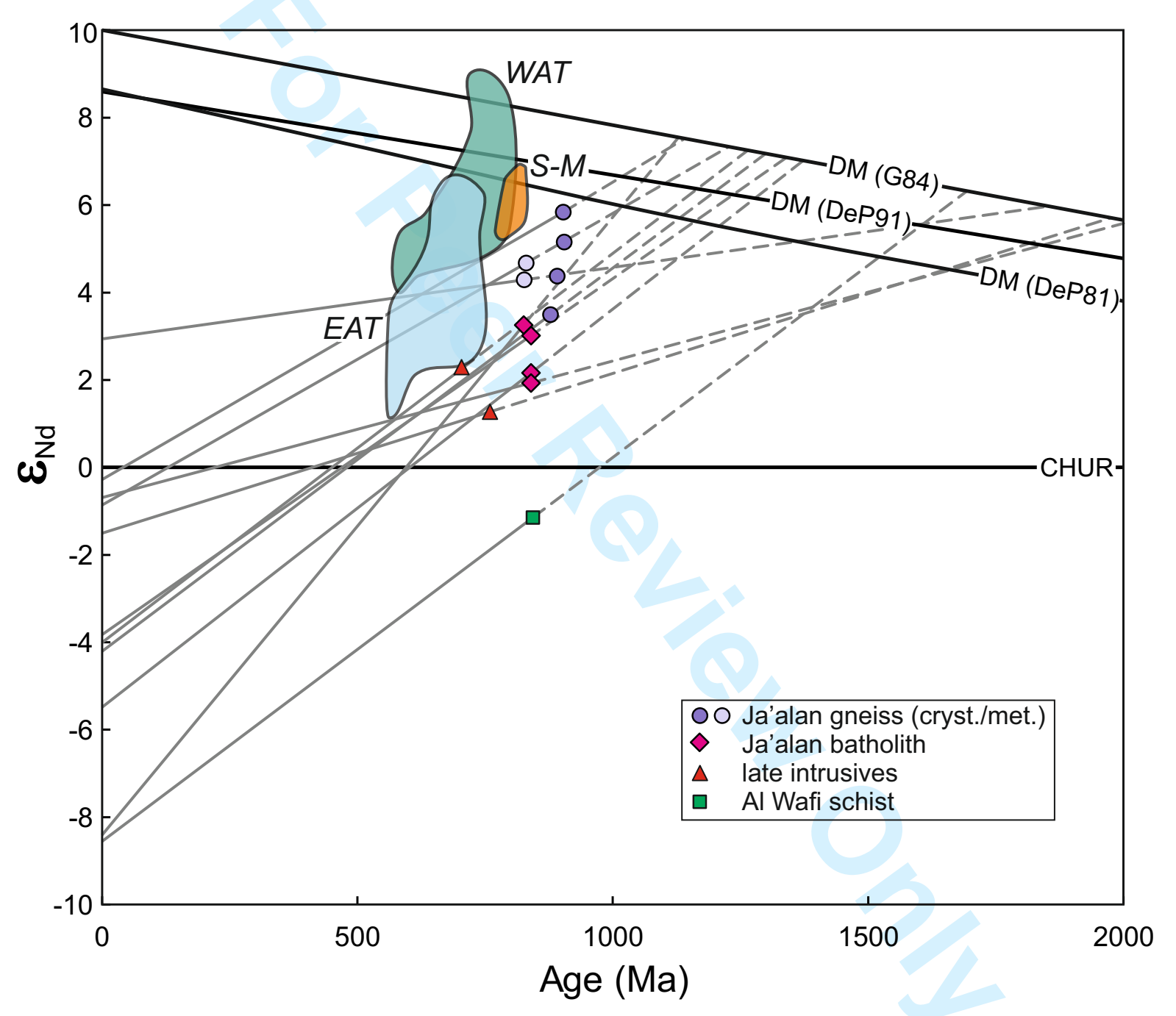

Whitehouse et al., Figure 10 URL: https://mc.manuscriptcentral.com/tigr E-mail: rjstern@utdallas.edu 


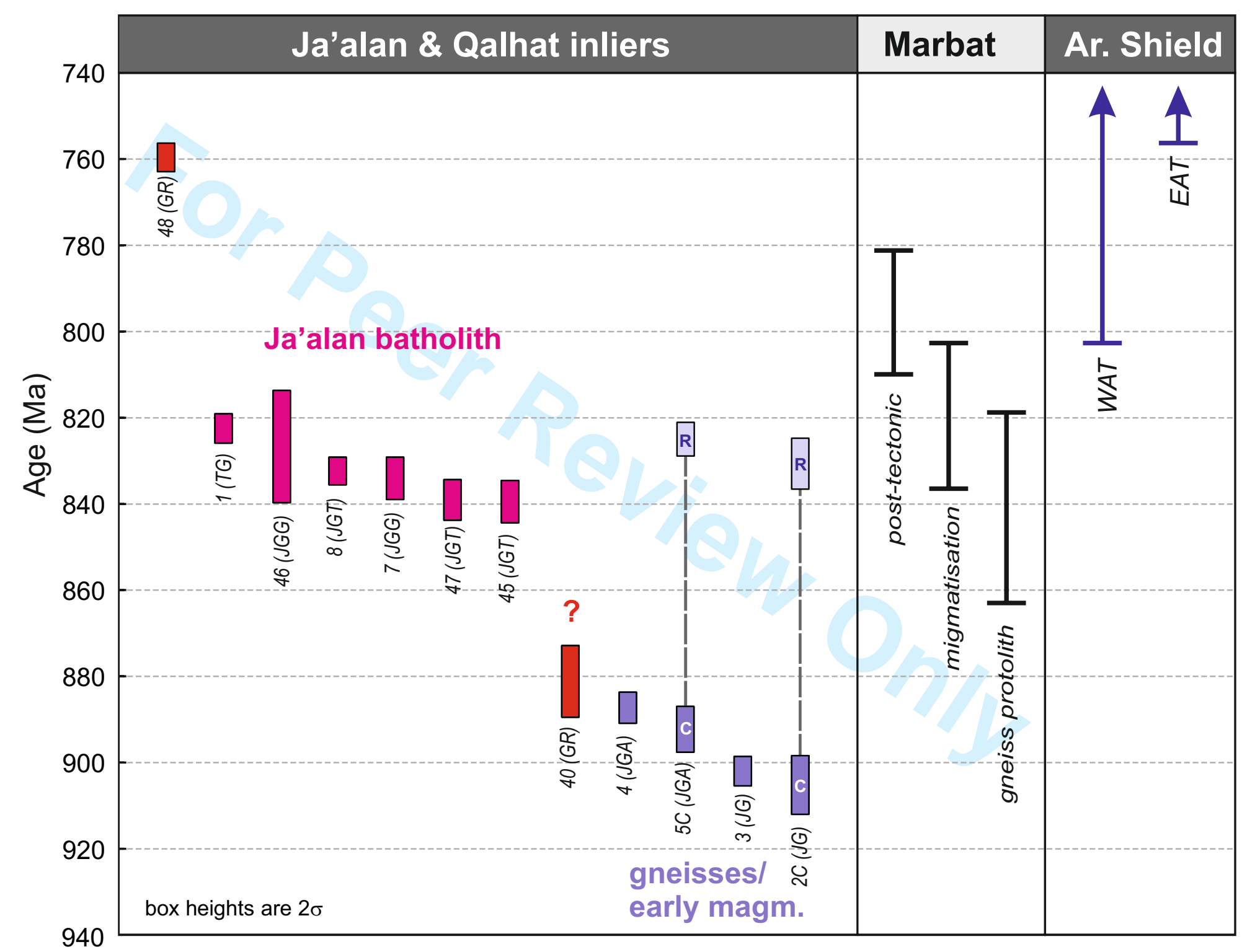


Table 1. Summary of Jebel Ja'alan and Qalhat samples

\begin{tabular}{lcccc}
\hline Sample ID & N. Latitude & E. Longitude & Rock type (map unit) & Age (Ma) \\
\hline OM05-40 & $22^{\circ} 14.029^{\prime}$ & $25^{\circ} 20.255^{\prime}$ & granite sheet (GR) & $881 \pm 8$ \\
OM05-41 & $22^{\circ} 14.029^{\prime}$ & $59^{\circ} 20.255^{\prime}$ & mica schist (WM) & detrital \\
OM05-42 & $22^{\circ} 13.887^{\prime}$ & $59^{\circ} 20.960^{\prime}$ & gt-musc-granite (TG) & $>704$ \\
OM05-45 & $22^{\circ} 13.728^{\prime}$ & $59^{\circ} 21.397^{\prime}$ & granodiorite (JGT) & $840 \pm 5$ \\
OM05-46 & $22^{\circ} 06.187^{\prime}$ & $59^{\circ} 21.377^{\prime}$ & bi-granite (JG) & $826 \pm 13$ \\
OM05-47 & $22^{\circ} 06.418^{\prime}$ & $59^{\circ} 21.420^{\prime}$ & granodiorite (JGT) & $840 \pm 5$ \\
OM05-48 & $22^{\circ} 06.663^{\prime}$ & $59^{\circ} 21.416^{\prime}$ & granite porphyry (DI) & $760 \pm 3$ \\
OM06-01 & $22^{\circ} 10.190^{\prime}$ & $59^{\circ} 24.270$ & gt-bi-tonalite (TG) & $823 \pm 3$ \\
OM06-02 & $22^{\circ} 10.202^{\prime}$ & $59^{\circ} 24.309^{\prime}$ & migmatitic gneiss (JG) & cores $=905 \pm 7$ \\
OM06-03 & $22^{\circ} 10.215^{\prime}$ & $59^{\circ} 24.374^{\prime}$ & grey gneiss (JG) & $931 \pm 6$ \\
OM06-04 & $22^{\circ} 10.215^{\prime}$ & $59^{\circ} 24.374^{\prime}$ & amphibolite (JGA) & $888 \pm 4$ \\
& & & & \\
OM06-05 & $22^{\circ} 10.215^{\prime}$ & $59^{\circ} 24.374^{\prime}$ & amphibolite (JGA) & cores $=891 \pm 5$ \\
OM06-06 & $22^{\circ} 39.182^{\prime}$ & $59^{\circ} 23.274^{\prime}$ & gt-bi-gneiss (JG) & detrital \\
OM06-07 & $22^{\circ} 39.184^{\prime}$ & $59^{\circ} 23.234^{\prime}$ & gt-granite (JGG) & $832 \pm 5$ \\
OM06-08 & $22^{\circ} 39.177^{\prime}$ & $59^{\circ} 23.287$ & tonalite (JGT) & $837 \pm 3$ \\
\hline
\end{tabular}


Table 1. Summary of Jebel Ja'alan and Qalhat samples

\begin{tabular}{lcccc}
\hline Sample ID & N. Latitude & E. Longitude & Rock type (map unit) & Age (Ma) \\
\hline OM05-40 & $22^{\circ} 14.029^{\prime}$ & $25^{\circ} 20.255^{\prime}$ & granite sheet (GR) & $881 \pm 8$ \\
OM05-41 & $22^{\circ} 14.029^{\prime}$ & $59^{\circ} 20.255^{\prime}$ & mica schist (WM) & detrital \\
OM05-42 & $22^{\circ} 13.887^{\prime}$ & $59^{\circ} 20.960^{\prime}$ & gt-musc-granite (TG) & $>704$ \\
OM05-45 & $22^{\circ} 13.728^{\prime}$ & $59^{\circ} 21.397^{\prime}$ & granodiorite (JGT) & $840 \pm 5$ \\
OM05-46 & $22^{\circ} 06.187^{\prime}$ & $59^{\circ} 21.377^{\prime}$ & bi-granite (JJG) & $826 \pm 13$ \\
OM05-47 & $22^{\circ} 06.418^{\prime}$ & $59^{\circ} 21.420^{\prime}$ & granodiorite (JGT) & $840 \pm 5$ \\
OM05-48 & $22^{\circ} 06.663^{\prime}$ & $59^{\circ} 21.416^{\prime}$ & granite porphyry (DI) & $760 \pm 3$ \\
OM06-01 & $22^{\circ} 10.190^{\prime}$ & $59^{\circ} 24.270$ & gt-bi-tonalite (TG) & $823 \pm 3$ \\
OM06-02 & $22^{\circ} 10.202^{\prime}$ & $59^{\circ} 24.309^{\prime}$ & migmatitic gneiss (JG) & cores $=905 \pm 7$ \\
OM06-03 & $22^{\circ} 10.215^{\prime}$ & $59^{\circ} 24.374^{\prime}$ & grey gneiss (JG) & $831 \pm 6$ \\
OM06-04 & $22^{\circ} 10.215^{\prime}$ & $59^{\circ} 24.374^{\prime}$ & amphibolite (JGA) & $888 \pm 4$ \\
OM06-05 & $22^{\circ} 10.215^{\prime}$ & $59^{\circ} 24.374^{\prime}$ & amphibolite (JGA) & cores $=891 \pm 5$ \\
OM06-06 & $22^{\circ} 39.182^{\prime}$ & $59^{\circ} 23.274^{\prime}$ & gt-bi-gneiss (JG) & detrital \\
OM06-07 & $22^{\circ} 39.184^{\prime}$ & $59^{\circ} 23.234^{\prime}$ & gt-granite (JGG) & $832 \pm 5$ \\
OM06-08 & $22^{\circ} 39.177^{\prime}$ & $59^{\circ} 23.287$ & tonalite (JGT) & $837 \pm 3$ \\
\hline
\end{tabular}


Table 2. Sm-Nd data from Ja'alan and Qalhat samples

\begin{tabular}{|c|c|c|c|c|c|c|c|c|c|c|c|}
\hline Sample ID & Rock type & Sm ppm & Nd ppm & ${ }^{143} \mathrm{Nd} /{ }^{144} \mathrm{Nd}$ & $2 \sigma_{M} \%$ & ${ }^{147} \mathrm{Sm} /{ }^{144} \mathrm{Nd}$ & $\varepsilon_{\mathrm{Nd}}(0)$ & $t_{\text {CHUR }}$ (Ma) & $t_{D M}(M a)^{1}$ & $t(\mathrm{Ma})^{2}$ & $\varepsilon_{\mathrm{Nd}}(\mathrm{t})$ \\
\hline OM05-40 & granite & 3.58 & 16.91 & 0.51242 & 0.0007 & 0.128 & -4.2 & 480 & 1199 & 881 & 3.4 \\
\hline OM05-41 & schist & 5.35 & 25.24 & 0.512197 & 0.0007 & 0.128 & -8.6 & 974 & 1604 & 850 & -1.2 \\
\hline OM05-42 & granite & 4.38 & 20.83 & 0.512431 & 0.0007 & 0.127 & -4 & 449 & 1165 & 704 & 2.2 \\
\hline OM05-45 & granodiorite & 4 & 14.08 & 0.5126 & 0.0007 & 0.172 & -0.7 & 223 & 1837 & 840 & 1.9 \\
\hline OM05-46 & granite & 3.12 & 21.95 & 0.512204 & 0.0007 & 0.086 & -8.4 & 596 & 1060 & 826 & 3.2 \\
\hline OM05-47 & granodiorite & 5.87 & 26.71 & 0.51244 & 0.0007 & 0.133 & -3.8 & 470 & 1236 & 839 & 2.9 \\
\hline OM05-48 & granite porph & 9.1 & 32.82 & 0.512559 & 0.0007 & 0.168 & -1.5 & 410 & 1812 & 760 & 1.2 \\
\hline OM06-02 & gneiss & 6.31 & 26.41 & 0.512592 & 0.0006 & 0.1445 & -0.9 & 129 & 1104 & 905 & 5.1 \\
\hline OM06-03 & gneiss & 10.68 & 45.01 & 0.512622 & 0.0006 & 0.1434 & -0.3 & 40 & 1019 & 902 & 5.8 \\
\hline OM06-05 & amphibolite & 8.81 & 28.98 & 0.512787 & 0.0007 & 0.1838 & 2.9 & $<0$ & 1597 & 891 & 4.3 \\
\hline OM06-08 & tonalite & 6.37 & 30.69 & 0.512355 & 0.0005 & 0.1254 & -5.5 & 602 & 1278 & 837 & 2 \\
\hline
\end{tabular}

Notes: 1) Depleted mantle model age uses model of DePaolo et al. (1991); 2) age from U-Pb zircon (this study) 
Table S1. Ja'alan and Qalhat igneous geochemistry

\begin{tabular}{|c|c|c|c|c|c|c|c|c|c|c|c|c|}
\hline $\begin{array}{l}\text { Sample } \\
\text { Rock type } \\
\text { Unit } \\
\end{array}$ & $\begin{array}{c}\text { OM05-40 } \\
\text { granite } \\
\text { GR } \\
\end{array}$ & $\begin{array}{c}\text { OM05-42 } \\
\text { granite } \\
\text { TG } \\
\end{array}$ & $\begin{array}{c}\text { OM05-45 } \\
\text { granodiorite } \\
\text { JGT }\end{array}$ & $\begin{array}{c}\text { OM05-46 } \\
\text { granite } \\
\text { JGG }\end{array}$ & $\begin{array}{c}\text { OM05-47 } \\
\text { granodiorite } \\
\text { JGT }\end{array}$ & $\begin{array}{c}\text { OM05-48 } \\
\text { granite } \\
\text { DI }\end{array}$ & $\begin{array}{c}\text { OM06-01 } \\
\text { tonalite } \\
\text { TG } \\
\end{array}$ & $\begin{array}{c}\text { OM06-02 } \\
\text { gneiss } \\
\text { JG }\end{array}$ & $\begin{array}{c}\text { OM06-03 } \\
\text { gneiss } \\
\text { JG }\end{array}$ & $\begin{array}{c}\text { OM06-04 } \\
\text { gneiss } \\
\text { JGA }\end{array}$ & $\begin{array}{c}\text { OM06-05 } \\
\text { gneiss } \\
\text { JGA }\end{array}$ & $\begin{array}{c}\text { OM06-08 } \\
\text { tonalite } \\
\text { JGT }\end{array}$ \\
\hline \multicolumn{13}{|c|}{ dry totals (wt. \%) } \\
\hline SiO2 & 74.43 & 75.84 & 62.51 & 72.26 & 56.58 & 79.47 & 55.51 & 70.57 & 70.97 & 49.03 & 49.51 & 52.83 \\
\hline Al2O3 & 14.81 & 13.45 & 17.84 & 14.41 & 15.88 & 11.52 & 20.25 & 14.69 & 13.55 & 14.43 & 14.76 & 21.07 \\
\hline $\mathrm{CaO}$ & 1.16 & 0.69 & 3.52 & 1.82 & 5.44 & 0.50 & 5.63 & 0.93 & 1.21 & 9.46 & 8.79 & 7.43 \\
\hline MgO & 0.25 & $b d$ & 1.86 & 0.76 & 5.81 & 0.09 & 2.05 & 1.92 & 2.01 & 6.74 & 6.50 & 2.85 \\
\hline Mno & 0.03 & 0.03 & 0.10 & 0.04 & 0.13 & bd & 0.31 & 0.11 & 0.04 & 0.26 & 0.24 & 0.17 \\
\hline P2O5 & 0.03 & 0.10 & 0.30 & 0.06 & 0.25 & bd & 0.52 & 0.03 & bd & 0.23 & 0.20 & 0.47 \\
\hline $\mathrm{Fe} 2 \mathrm{O} 3$ & 1.23 & 1.71 & 5.93 & 2.21 & 8.37 & 0.90 & 8.49 & 4.84 & 3.64 & 13.7 & 13.4 & 8.03 \\
\hline $\mathrm{Na2O}$ & 4.03 & 3.15 & 4.30 & 3.59 & 3.14 & 3.46 & 3.38 & 4.08 & 1.98 & 2.84 & 2.91 & 3.87 \\
\hline K2O & 3.76 & 4.95 & 2.63 & 4.34 & 2.78 & 3.92 & 2.62 & 1.96 & 6.05 & 1.07 & 1.66 & 1.78 \\
\hline TiO2 & 0.14 & 0.42 & 0.84 & 0.31 & 1.33 & 1.00 & 1.02 & 0.73 & 0.28 & 2.10 & 1.89 & 1.32 \\
\hline Total & 99.85 & 100.33 & 99.84 & 99.79 & 99.71 & 100.85 & 99.79 & 99.87 & 99.73 & 99.87 & 99.85 & 99.80 \\
\hline LOI & 0.76 & 0.42 & 2.86 & 0.76 & 2.31 & 1.00 & 2.89 & 2.21 & 0.99 & 0.68 & 1.39 & 1.66 \\
\hline \multicolumn{13}{|c|}{ CIPW normative mineralogy } \\
\hline$q$ & 33.5 & 36.5 & 15.9 & 29.2 & 5.6 & 42.8 & 8.6 & 32.9 & 29.6 & -- & -- & 1.4 \\
\hline$c$ & 2.1 & 1.9 & 2.2 & 0.6 & 0.0 & 0.8 & 2.8 & 4.3 & 1.6 & -- & -- & 0.4 \\
\hline or & 22.3 & 29.3 & 15.6 & 25.7 & 16.4 & 23.2 & 15.5 & 11.6 & 35.8 & 6.3 & 9.8 & 10.5 \\
\hline$a b$ & 34.0 & 26.6 & 36.3 & 30.4 & 26.6 & 29.2 & 28.6 & 34.5 & 16.7 & 24.0 & 24.6 & 32.7 \\
\hline an & 5.4 & 2.8 & 15.5 & 8.7 & 21.0 & 2.2 & 24.5 & 4.3 & 5.7 & 23.5 & 22.3 & 33.8 \\
\hline$d i$ & -- & -- & -- & -- & 3.6 & -- & -- & -- & -- & 18.1 & 16.4 & 0.0 \\
\hline hy & 1.5 & 1.9 & 9.4 & 3.4 & 20.2 & 1.2 & 13.0 & 8.6 & 7.8 & 10.8 & 7.8 & 14.3 \\
\hline ol & -- & -- & -- & -- & -- & -- & -- & -- & -- & 8.5 & 10.8 & -- \\
\hline$m t$ & 0.6 & 0.8 & 2.3 & 1.0 & 2.6 & 0.4 & 2.9 & 1.9 & 1.6 & 3.0 & 3.0 & 2.5 \\
\hline il & 0.3 & 0.2 & 1.6 & 0.6 & 2.5 & 0.2 & 1.9 & 1.4 & 0.5 & 4.0 & 3.6 & 2.5 \\
\hline$a p$ & 0.1 & 0.2 & 0.7 & 0.1 & 0.6 & 0.1 & 1.1 & 0.1 & 0.1 & 0.5 & 0.4 & 1.0 \\
\hline
\end{tabular}

Note: Normative mineralogy after Cox, Bell, and Pankhurst (1979) with iron oxidation state after Middlemost (1989). 
A

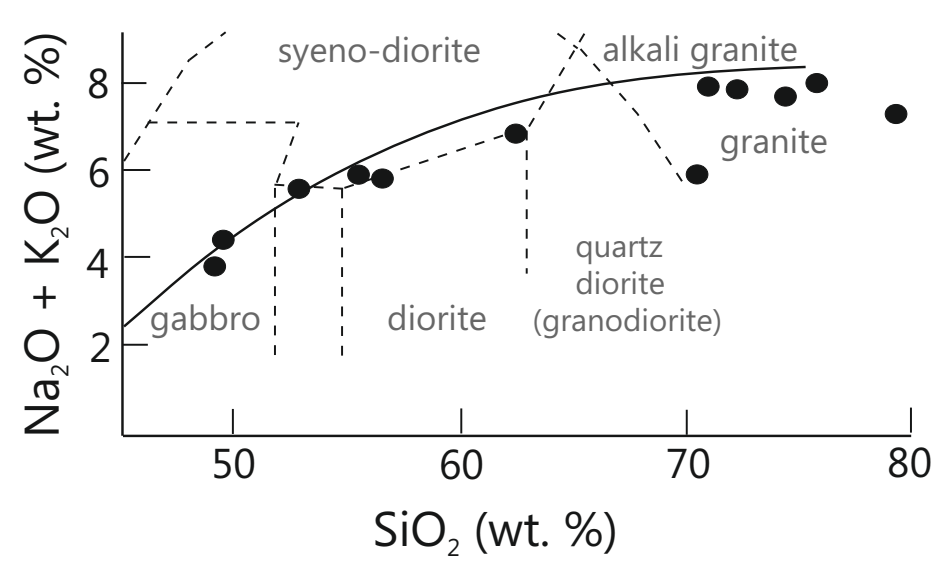

B

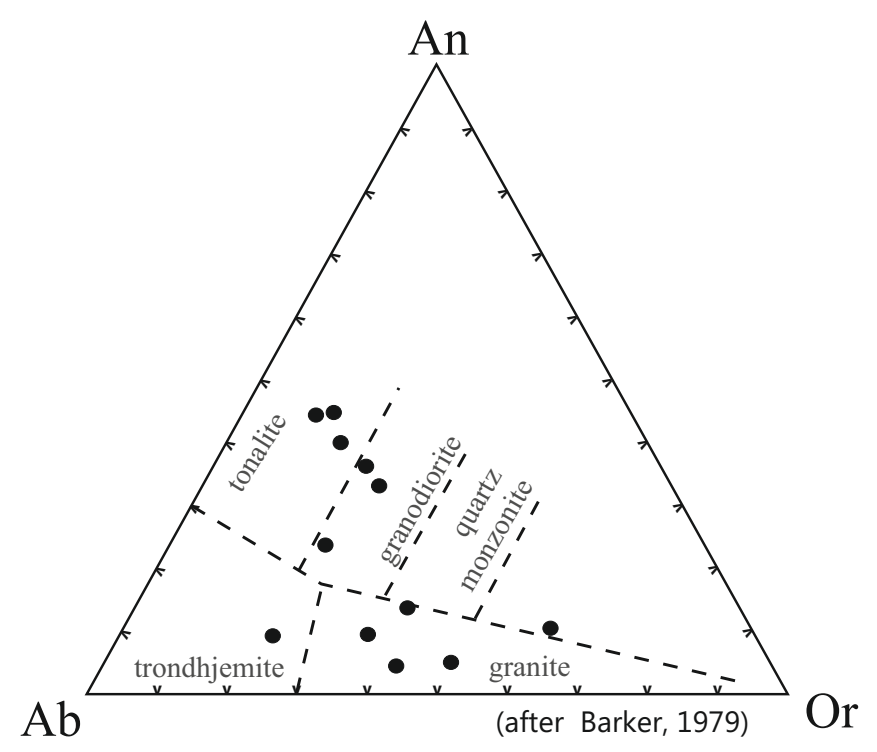

